\title{
Reactive Oxygen Species in Cardiovascular Disease
}

\author{
Koichi Sugamura and John F. Keaney Jr.* \\ Division of Cardiovascular Medicine, Department of Medicine, University of Massachusetts \\ Medical School, Massachusetts 01605
}

\begin{abstract}
Based on the 'free-radical theory' of disease, researchers have been trying to elucidate the role of oxidative stress from free radicals in cardiovascular disease. Considerable data indicate that ROS and oxidative stress are important features of cardiovascular diseases including atherosclerosis, hypertension, and congestive heart failure. However, blanket strategies with antioxidants to ameliorate cardiovascular disease have not generally yielded favorable results. However, our understanding or reactive oxygen species has evolved to the point that we now realize these species have important roles in physiology as well as pathophysiology. Thus, it is overly simplistic to assume a general antioxidant strategy will yield specific effects on cardiovascular disease. Indeed, there are several sources of reactive oxygen species that are known to be active in the cardiovascular system. This review will address our understanding of reactive oxygen species sources in cardiovascular disease and both animal and human data defining how reactive oxygen species contribute to physiology and pathology.
\end{abstract}

\section{Keywords}

reactive oxygen species; biomarkers; clinical trials; cardiovascular disease

\section{Introduction}

In the beginning of 20th century, 'The rate-of-living hypothesis' was derived from observations that animals with higher metabolic rates were characterized by shorter life spans, implying that a species metabolic rate ultimately determines its life expectancy. In 1956, Denham Harman proposed a 'free-radical theory' that endogenous oxygen radicals were generated in cells over time resulting in cumulative cellular damage targeting DNA, protein, lipids and other components of the cell [1]. Since cardiovascular disease is a manifestation of aging, researchers have attempted to elucidate the relation between cardiovascular disease and oxidative stress caused by free radicals.

\section{Clinical studies of antioxidants in vascular disease}

Initially, these studies focused on how antioxidants may influence the clinical course of atherosclerosis and cardiovascular disease. Numerous clinical trials have been performed to

(C) 2011 Elsevier Inc. All rights reserved.

*To whom correspondence should be addressed: University of Massachusetts Medical School, Department of Medicine/ Division of Cardiovascular Medicine, 381 Plantation St., Biotech 5, Suite 200, Worcester, MA 01605., Phone: 508-856-6904, Fax : 508-856-6933, john.keaney@umassmed.edu.

Publisher's Disclaimer: This is a PDF file of an unedited manuscript that has been accepted for publication. As a service to our customers we are providing this early version of the manuscript. The manuscript will undergo copyediting, typesetting, and review of the resulting proof before it is published in its final citable form. Please note that during the production process errors may be discovered which could affect the content, and all legal disclaimers that apply to the journal pertain. 
examine the potential for preventing cardiovascular disease using antioxidant therapies (please see Table 1). The term, cardiovascular disease encompasses the major clinical endpoints related to the heart and vascular system including myocardial infarction (MI; heart attack), ischemic heart disease (MI and angina), stroke, and peripheral arterial disease (ischemia of the limbs). The most common manifestations of cardiovascular disease are MI and stroke. Thus, a predominance of studies investigating antioxidant status focus on cardiovascular disease (CVD) with combined endpoints of stroke and MI, whereas some focus on MI using the term coronary heart disease (CHD).

\section{Primary prevention of vascular disease}

Some antioxidant studies have focused on the primary prevention of CVD, meaning the prevention of CVD in patients that do not already have the disease. Observational studies of vitamin $\mathrm{C}$ in the primary prevention of CVD have been conflicting with only some suggesting a benefit with the consumption of vitamin C supplements [2-8]. Large-scale randomized trials evaluating vitamin $\mathrm{C}$ indicate no effect on the primary endpoint of CVD and no meaningful impact on all-cause mortality $[9,10]$. In contrast, observational studies of vitamin $\mathrm{E}$ supplementation predominantly found that vitamin $\mathrm{E}$ was associated with a lower risk of CHD [6, 7, 11, 12]. These findings were of considerable interest, but had to be interpreted with caution as observational trials are subject to unintended bias and confounding. Thus, several randomized, double-blind, placebo-controlled trials were conducted to investigate the impact of vitamin E supplementation on CVD and none have found a benefit for the primary prevention of CVD [9, 13-16]. In fact, evidence from some of these trials found that vitamin E treatment was associated with increased heart failure [17] and hemorrhagic stroke [9]. Beta carotene has also been investigated and randomized trials of this antioxidant failed to show any effect on the primary prevention of CHD or the risk of death from CVD [13, 18-20]. Thus, it has been difficult to demonstrate that antioxidant supplementations (vitamin $\mathrm{C}, \mathrm{E}$ and beta carotene) have an impact on the primary prevention of CHD or CVD.

\section{Secondary Prevention of vascular disease}

Secondary prevention refers to inhibiting manifestations of CVD in those patients who already have the disease. Since the risk of a second cardiovascular event (MI, stroke, angina) is highest in patients that have already had a first event, established prevention measures (e.g. cholesterol lowering, smoking cessation, etc.) are most effective in secondary prevention. Thus, if antioxidant therapy were to be of benefit, it would be expected to be most effective in secondary prevention. However, treatment of postmenopausal women with CHD using vitamins $\mathrm{C}$ and $\mathrm{E}$ showed no benefit on CHD and even demonstrated excess death compared to placebo [21]. Similarly, in women with CHD or at high risk for CHD, treatment with vitamin $\mathrm{C}, \mathrm{E}$, and beta carotene, either alone or combination, did not show any benefits on cardiovascular events [22]. With regards to vitamin $\mathrm{E}$ alone, there are two trials that suggested a benefit. The Cambridge Heart Antioxidant Study (CHAOS), demonstrated a benefit for vitamin $\mathrm{E}$ in patients with coronary disease, but no impact on mortality [23], and in patients with kidney disease the administration of vitamin E significantly reduced the incidence of cardiovascular events [24]. However, in other large scale randomized trials, vitamin $\mathrm{E}$ administration alone or in combination had no effect on cardiovascular outcome [25]. With beta carotene, there is no convincing evidence of a benefit on angina [26], and it may be harmful for patients with previous MI because of increased cardiac death [27]. Thus, on balance, these results lead the conclusion that there is no consistent evidence of benefit from vitamin $\mathrm{C}, \mathrm{E}$ and beta carotene for the secondary prevention of CHD. This conclusion is also supported by meta-analyses looking at all the trials collectively [28]. 
Other synthetic antioxidants have been studied in human clinical trials including probucol and succinobucol. Probucol was originally developed as a lipid lowering agent and then also noted to be a potent antioxidant that prevents endothelial dysfunction $[29,30]$ and (low density lipoprotein) LDL oxidation [31]. Pretreatment with probucol significantly reduced the arterial response to injury compared to placebo [32-34], suggesting promise for the treatment of atherosclerosis. However, in one large clinical study probucol did not have a significant impact on femoral artery atherosclerosis [35]. Moreover, probucol is no longer available for clinical use due to prolongation of the QT interval and potential pro-arrhythmic effects. Succinobucol is a probucol derivative with antioxidant efficacy[36] that lacks QTinterval prolonging effects. However, a large scale randomized clinical trial with this drug added to conventional treatments had no effect on cardiovascular death, resuscitated cardiac arrest, MI, stroke, unstable angina, or coronary revascularization [37].

On balance, these trials have not demonstrated clinical efficacy of antioxidant treatment to ameliorate the clinical manifestations of atherosclerosis. There have been multiple reasons proffered, including the notion that the effects of ROS are complex, making outcome predictions difficult, and that the types of antioxidants, their dosage, and their duration of action have been inadequate [38-41]. It is also known that genetic factors influence the response to antioxidants [42-44], raising the possibility that only some patients will benefit from antioxidant treatment and that we lack the ability to identify this subset of patients. This latter point deserves particular attention. During the time of many clinical studies, there was not an agreed upon manner to identify patients who suffer from an excess of vascular oxidative stress that would be most likely to benefit from antioxidant treatment. In fact, we do not really know what proportion of CVD patients might fit into this category. As a consequence, we could be treating large numbers of patients with only a small fraction likely to benefit. Thus, in the future it may make more sense to measure oxidative stress markers, such as F2-isoprostanes that have been used successfully clinically [45], as a means to target appropriate patients and document appropriate antioxidant efficacy.

Another compelling explanation for the mixed performance of general antioxidant treatment in mitigating cardiovascular disease is the incomplete knowledge of how reactive oxygen species (ROS) impact both physiology and pathophysiology. There is now overwhelming evidence that ROS have a role as second messengers for cellular signal transduction, and the balance between oxidizing and reducing species is known to be an important component of cellular homeostasis (Figure 1) [46, 47]. Thus, the premise that one can selectively scavenge "pathological" vs. "physiological" ROS with specific antioxidants is likely not valid. Consequently, it may be more fruitful to understand the mechanisms whereby ROS are produced and the source(s) of ROS than to focus on a strategy directed at ROS scavenging.

\section{Selected sources of reactive oxygen species (ROS) in cardiovascular disease}

A variety of enzymatic and non-enzymatic processes can generate ROS in mammalian cells. Some of the most important sources are the mitochondrial respiratory chain, nicotinamide adenine dinucleotide phosphate (NADPH) oxidases, xanthine oxidase, lipoxygenase, uncoupled nitric oxide synthase (NOS) and myeloperoxidase (MPO) and these systems are depicted in Figure 2. There is evidence linking each of these sources with CVD pathology (Table 2) and, as a consequence, we will discuss each in turn below.

\section{Mitochondrial respiratory chain}

Mitochondria have long been known as an important source of ROS generation. Of the entire electron flux through mitochondria, more than $97 \%$ is utilized to reduce cellular 
oxygen to water [48]. Estimates from experiments in isolated mitochondria estimate a 2 $3 \%$ leakage of electrons to form $\mathrm{O}_{2}{ }^{\cdot-}$ that is largely dismutated to $\mathrm{H}_{2} \mathrm{O}_{2}$ by manganese superoxide dismutase (Mn-SOD) in the mitochondrial matrix [48]. The importance of removing mitochondrial $\mathrm{O}_{2}{ }^{--}$is emphasized by observations that animals null for the MnSOD allele exhibit perinatal lethality due to cardiac dysfunction [49] and cardiac-specific Mn-SOD deletion produces progressive congestive heart failure with specific molecular defects in mitochondrial respiration [50]. It is also important to realize that Mn-SOD generates $\mathrm{H}_{2} \mathrm{O}_{2}$, another ROS with pathophysiologic importance as overexpression of peroxiredoxin-3 (a mitochondrial $\mathrm{H}_{2} \mathrm{O}_{2}$ scavenger) prevents heart failure after experimental $\mathrm{MI}$ in mice [51]. Collectively, data indicate that mitochondria are an important source of ROS that has implications for the cardiovascular system.

\section{Nicotinamide adenine dinucleotide phosphate (NADPH) oxidase}

The NADPH oxidases are a family of multiple-subunit complex enzymes that generate $\mathrm{O}_{2}{ }^{--}$ via one electron reduction of oxygen using NADPH as an electron source. Interested readers are directed to a recent excellent review of this enzyme family [52]. In brief, the prototypical NADPH oxidase (Nox2) consists of two membrane-bound subunits (gp91 and p22) and three or more cytoplasmic subunits (p40, p47, p67, G protein Rac1 or 2). Genetic defects of gp91, p22, p47, or p67 are the basis for the clinical syndrome of chronic granulomatous disease, because Nox2-derived ROS are necessary for host defense such as the killing of microorganisms by neutrophils and monocytes. There are a total of 7 Nox isoforms that are also present in non-phagocytic cells, including vascular endothelial cells, smooth muscle cells, fibroblasts and cardiomyocytes [53]. Data generated from experimental animals indicate roles for Nox isoforms in cardiac fibrosis [54], preconditioning [55], cardiac remodeling post-MI [56] and angiotensin II -dependent cardiac hypertrophy [57-60]. Within the vasculature, evidence indicates that Nox isoforms may contribute to atherosclerosis [6163], aortic aneurysm formation [64], and the response to arterial injury [65]. With regards to physiologic responses, Nox-derived ROS have been linked to endothelial cell migration and ischemia-induced angiogenesis [66]. Thus, there is ample evidence for Nox-derived ROS in modulating both vascular physiology and pathophysiology.

\section{Xanthine oxidase}

Xanthine oxidase and xanthine dehydrogenase are forms of the same enzyme, known as xanthine oxidoreductase. This enzyme is widely distributed in mammalian tissues and with particularly high expression in capillary endothelium [67]. Both forms of xanthine oxidoreductase catalyze the conversion of hypoxanthine to xanthine and xanthine to uric acid, however only the oxidase form generates $\mathrm{O}_{2}{ }^{--}$and $\mathrm{H}_{2} \mathrm{O}_{2}$ [68]. The enzyme typically exists in the dehydrogenase form, but under certain stressful conditions, such as hypoxia, the oxidase isoform predominates [69]. Xanthine oxidase has been implicated as a source of ROS after reperfusion of ischemic tissue in several organs [70-72]. However, genetic evidence is lacking since xanthine dehydrogenase-null mice are runted and die by 6 weeks of age from renal dysplasia [73]. As a consequence, most of the data implicating xanthine oxidase relies on pharmacologic inhibition via allopurinol or oxypurinol, or by administration of a tungsten-rich, molybdenum deficient diet to experimental animals, which leads to an inactive enzyme [74] and is associated with reduced atherosclerosis [75]. In addition to ROS production, xanthine oxidase may act as a $\mathrm{NO}_{3}{ }^{-}$and $\mathrm{NO}_{2}{ }^{-}$reductase to generate nitric oxide (NO) under hypoxic conditions [76-79]. In addition, xanthine oxidase expression and $\mathrm{O}_{2}{ }^{--}$production are upregulated by NADPH oxidase [80], indicating that factors regulating NADPH oxidase may also have influence on xanthine oxidase [81]. 


\section{Lipoxygenases}

The lipoxygenases are non-heme, iron-containing enzymes that catalyze the stereospecific incorporation of molecular oxygen into polyunsaturated fatty acids [82]. Certain lipoxygenase isoforms are thought to promote atherosclerosis by generating ROS and oxidatively modified lipids, like oxidized low density lipoprotein (Ox-LDL) [83]. The 12/15-lipoxygenase (12/15-LO; also known as the leukocyte-type 12-lipoxygenase and 15lipoxygenase-1) and 5-lipoxygenase (5-LO) are most studied because of their expression pattern in inflammatory cells and endothelial cells [84]. Lipoxygenases are the key enzymes in the biosynthesis of leukotrienes that are playing an important pathophysiological role in inflammatory diseases. Reactive oxygen species are generated as a byproduct during the biosynthesis step of leukotrienes by lipoxygenases[84]. In human atherosclerotic lesions, 5LO is present in macrophages, foam cells, mast cells and dendritic cells [85] and 12/15-LO is widely distributed to including blood vessels, the brain, and the kidneys [86].

There is considerable genetic evidence that lipoxygenases can participate in cardiovascular physiology and pathophysiology. Mice lacking 12/15-LO exhibit decreased atherosclerosis in a number of models [87-90]. Consistent with these observations, 12/15-LO has been implicated in a number of events important for atherosclerosis such as cytokine production [91] and the adhesion of monocytes to endothelial cells [92-94]. The 5-LO has been implicated in atherosclerosis susceptibility in mice [90], suggesting that the lipoxygenases represent a source of ROS that is relevant to CVD.

Given the available data in animal models, lipoxygenases have been investigated with regards to human cardiovascular disease [95]. During the period from early to advanced atherosclerosis, the quantity of 5-LO positive cells are increased in human atherosclerotic plaque specimens [96] and elevated 5-LO activity has been linked to plaque instability [97]. In human abdominal aortic aneurysm tissue, 5-LO is expressed in macrophage-rich adventitial areas and associated with intraluminal thrombus [98]. Thus, targeting the 5-LO pathway could potentially reduce CHD or abdominal aortic aneurysm. To this end, a recent study reported that a potent 5-LO inhibitor reduced leukotriene production and coronary plaque burden (by CT scan) in patients after acute coronary syndrome [99]. Since this study is preliminary and the observation period is relatively short (6 months), these results require confirmation in larger scale trials of longer duration. Another drug of interest is an inhibitor of 5-LO activating protein (FLAP), known as DG031. This compound was shown to reduce biomarkers of cardiovascular risk in patients with genetic variants of the gene for 5-LO activating protein [100].

\section{Nitric oxide synthases (NOSs)}

The NOS enzymes are a family that catalyze the conversion of L-arginine to L-citrulline with the production of NO. There are three NOS isoforms that are termed neuronal NOS (nNOS), endothelial NOS (eNOS), and inducible NOS (iNOS) based upon the tissues in which they were first described (reviewed in [101]). In most cardiovascular tissues in which they are expressed, nNOS and eNOS are constitutively present, but in distinct subcellular locations. In contrast, iNOS is usually absent, but induced by pro-inflammatory mediators [102]. The bulk of evidence linking NOS production of ROS pertains to the eNOS isoform. Active eNOS exists as a homodimer with each monomer consisting of reductase and oxygenase domains [103]. The production of NO via eNOS involves electron transfer from the cofactor NADPH to flavin adenine dinucleotide and flavin adenine mononucleotide to heme. This electron transfer affords oxidation of L-arginine is oxidized to form NO and Lcitrulline, with the assistance of tetrahydrobiopterin $\left(\mathrm{BH}_{4}\right)$ as a cofactor. The tight coupling of electron flow through eNOS to L-arginine is dependent upon adequate levels of cofactors and, under specific circumstances, eNOS may become "uncoupled" and reduce molecular 
oxygen rather than transfer electrons to L-arginine, there by generating $\mathrm{O}_{2}{ }^{--}$as an important source of ROS [104]. The most labile eNOS cofactor is $\mathrm{BH}_{4}$ and, as a consequence, it is also the most common in vivo mechanism for eNOS uncoupling. Although all NOS isoforms are capable of uncoupled NO production, it is most often described with eNOS.

The data for eNOS uncoupling in vivo spans animal and human data. With regard to the former, platelets contain eNOS and platelets isolated from eNOS-null mice produce less $\mathrm{O}_{2}{ }^{--}$than wild-type platelets [105]. Cholesterol-fed animals also exhibit eNOS uncoupling that is linked to the amount of $\mathrm{BH}_{4}$ in vascular tissues [106]. We know that these findings are clinically relevant, as arterial segments from humans with diabetes [107] or atherosclerosis [108] exhibit eNOS uncoupling. The uncoupling is reversible, however, as treatment with 5-methyl tetrahydrofolate (5-MTHF; the active form of folic acid), which increases intracellular $\mathrm{BH}_{4}$ levels, also decreases vascular superoxide production [109]. Although the substantial long-term folic acid and vitamin B12 supplementation did not have beneficial effects on vascular outcomes [110], 5-MTHF has a direct anti-atherogenic effects by decreasing vascular superoxide generation and augmenting NO bioavailability in the human vascular wall $[109,111]$. The methyl tetrahydrofolate reductase gene polymorphism which affected plasma or circulating 5-MTHF exerts a direct effect on vascular $\mathrm{BH}_{4}$ levels, NO bioavailability, and eNOS coupling in human vessels in vivo [112].

Thus, it appears the impact of eNOS on the vasculature can depend upon whether there are appropriate levels of cofactors to support eNOS function. Data on atherosclerosis support this contention as eNOS-null animals on an apolipoprotein E (ApoE)-null background exhibit more atherosclerosis than ApoE-null mice alone [113], whereas overexpression of eNOS in ApoE-null mice shown increased atherosclerotic lesion formation with elevated levels of vascular $\mathrm{O}_{2}{ }^{--}$[114]. These findings were explained by a relative deficiency in $\mathrm{BH}_{4}$ with eNOS overexpression leading to eNOS uncoupling. Consistent with this hypothesis, overexpression of GTP-cyclohydrolase I (the rate-limiting enzyme for $\mathrm{BH}_{4}$ synthesis) prevents eNOS uncoupling [115] and reduces atherosclerosis and ROS levels [116, 117].

In the heart, eNOS is not only expressed in the endothelium, but also in cardiac myocytes. In general, evidence supports cardiac eNOS as a protective enzyme. Genetic eNOS deletion increased long-term mortality and attenuated left ventricular (LV) function in mice with MI [118]. In the case of pressure overload induced by aortic constriction, eNOS-null mice exhibited more severe LV hypertrophy, LV dysfunction, and myocardial fibrosis than in wild-type mice [119]. Consistent with eNOS as a protective factor, eNOS overexpression protects against $\mathrm{MI}$ and ischemic reperfusion injury compared to the wild-type phenotype [120, 121]. Cardiac-specific overexpression of eNOS also attenuates the LV hypertrophy induced by coronary artery occlusion [122] and eNOS-null mice with eNOS restored only in the myocardium showed less LV hypertrophy and dysfunction caused from pressure overload than mice with global eNOS deletion [123]. As one might expect given the deleterious effects of eNOS uncoupling, $\mathrm{BH}_{4}$ replacement therapy rescued pressure overload-induced LV hypertrophy, fibrosis, and cardiomyocyte dysfunction after aortic constriction and these effects were associated with less oxidant stress and recoupled eNOS [124]. Thus, functional eNOS in either the endothelium or the cardiac myocyte appears to promote adaptive responses in the heart.

The two other NOS isoforms, iNOS and nNOS have also been investigated in the cardiovascular system, although the contribution of uncoupling is less clear. Several studies performed in iNOS-null mice on the ApoE-null background show a significant reduction in atherosclerotic plaque formation [125-127]. In an experimental MI model, iNOS-null mice showed increased contractility and decreased mortality compared to wild-type mice [128]. In an aortic constriction model, iNOS-null mice demonstrated much less hypertrophy, 
dilatation, fibrosis, and dysfunction of the LV, than wild-type mice [129]. Conversely, myocardial overexpression of iNOS in mice demonstrated cardiac fibrosis, cardiomyocyte death, cardiac hypertrophy, and LV dilatation. These mice developed overt heart failure and most of them died suddenly from atrioventricular block and asystole [130]. One possible mechanism may be an iNOS-mediated oxidation of $\mathrm{BH}_{4}$ needed for eNOS-mediated NO production [131].

With regards to nNOS, nNOS-null mice on the ApoE-null background demonstrated promotion of atherosclerosis formation [132]. One potential explanation for the above observations is that nNOS inhibits xanthine oxidoreductase activity and in nNOS-null mice the production of ROS is increased [133]. With regards to the heart, nNOS-null mice with acute MI showed severe LV remodeling and a higher mortality rate than wild-type mice $[134,135]$. Conversely, cardiomyocyte-specific nNOS overexpression produced better preservation of LV function with pressure overload than wild-type mice [136]. Deletion with both the nNOS and eNOS genes produces spontaneous concentric left ventricular hypertrophy associated with interstitial fibrosis, impairment of LV diastolic properties, and high mortality [137].

\section{Myeloperoxidase}

MPO is a member of the heme peroxidase family of enzymes. This enzyme is expressed in neutrophils and monocytes, and it generates reactive species that can oxidatively modify lipids and proteins $[138,139]$. The MPO catalytic cycle typically involves the consumption of $\mathrm{H}_{2} \mathrm{O}_{2}$ to produce a range of oxidizing products. Amongst the MPO-derived oxidants in vivo, $\mathrm{HOCl}$ is the most abundant as physiologic chloride concentrations $(\sim 150 \mathrm{mM})$ favor its formation [140-142]. One notable feature of $\mathrm{HOCl}$ as an oxidant is the fact that it is a twoelectron oxidant and reacts poorly with one-electron antioxidants such as vitamin E. Thus, if $\mathrm{HOCl}$ were an important oxidant in the progression of atherosclerosis its chemical properties could provide an explanation for the poor track record of antioxidant supplementation in treating and preventing atherosclerosis.

There is considerable evidence that MPO produces oxidation during the course of atherosclerosis. Enzymatically-active MPO is abundant in monocyte-derived macrophages of human atherosclerotic lesions [143] that are co-localized with lipoproteins that show evidence of HOCl-mediated oxidation [144]. Oxidation from MPO has also been implicated in the transition of stable atherosclerotic plaques to a type more "vulnerable" to plaque rupture. The mechanism relates to MPO-generated $\mathrm{HOCl}$ that can lead to matrix metalloproteinase activation and lipid peroxidation in the artery wall [143, 145], two processes linked to forming unstable atherosclerotic plaques [146]. In addition to producing reactive chlorinating species in humans, MPO catalyzes the oxidation of NO in human plasma in a manner that can reduce the bioavailability of NO [147, 148]. These data, combined with observations that MPO-derived $\mathrm{HOCl}$ can induce endothelial dysfunction [149] and eNOS uncoupling [150], indicate that MPO significantly disrupts normal vascular homeostasis.

Efforts to model the impact of MPO on atherosclerosis have been difficult, in part, because murine atherosclerosis, unlike the human condition, does not demonstrate lesional MPO accumulation. Thus, the effects on animal atherosclerosis have been mixed. In low density lipoprotein receptor (LDL-R)-null mice, populating the bone marrow with MPO-null cells increases atherosclerosis [151], whereas populating the bone marrow with cells over expressing human MPO also increased atherosclerosis compared to wild-type bone marrow [152]. More recently, several studies with "humanized" MPO in murine models have supported the notion that MPO promotes atherosclerosis [152, 153]. Collectively, 
differences between human and murine MPO have made the appropriate modeling of human disease in mice challenging.

In contrast to the animal studies, human studies have been much more consistent with regards to the role of MPO on CVD and its outcomes. Patients with reduced MPO levels appear to have reduced CVD [154]. Leukocyte MPO levels are associated with the extent of coronary atherosclerosis [155] and circulating MPO levels are a good indicator of the presence and extent of coronary artery disease (CAD) [156, 157]. Finally, the activity of atherosclerosis is also predicted by MPO in apparently healthy individuals [158]. Thus, data from biochemical, animal, and human studies support a role for MPO and MPO-derived oxidants in the clinical course of atherosclerosis.

The precise mechanism for these observations is not known. However, MPO has recently been determined to have a significant impact on high density lipoprotein (HDL) and the process of reverse cholesterol transport. Apolipoprotein A-I (Apo A-I), the major protein component of HDL, contains a specific binding site for MPO [159, 160]. This HDL-bound MPO retains enzymatic activity and modifies Apo A-I in a manner that further enhances Apo A-I binding affinity for MPO [161]. The oxidation of Apo A-I also impairs the HDL particle capacity to promote cellular cholesterol efflux by ATP-binding cassette transporter 1 [160] and oxidized Apo A-I cannot activate lecithin:cholesterol acyltransferase, an enzyme important for HDL maturation [162]. Thus, MPO has the capacity to inhibit reverse cholesterol transport and HDL function, thereby promoting both atherosclerosis and the clinical activity of CVD.

\section{Detection of ROS in cardiovascular disease}

One strategy to determine the role of ROS in CVD involves looking for experimental evidence of oxidative reactions in clinical populations. A major challenge in monitoring ROS in biologic systems is the highly reactive nature of the compounds in question. Fluorescence probes have been designed that can detect individual ROS [163] and electron spin resonance probes exist that can provide information about the activity and location of free radical reactions [164]. However, these tools are limited in human and animal applications due to technical considerations [165]. As a consequence, there has been considerable effort directed at developing techniques to assess either the downstream consequences of ROS (e.g. oxidation products) or enzyme levels important for ROS reactions (e.g. myeloperoxidase). The levels of these biomarkers, therefore, can provide at least indirect evidence for ROS action in CVD.

\section{Oxidized low density lipoprotein (Ox-LDL)}

LDL contains lipid species that are subject to oxidation in the presence of several ROS known to exist in vascular wall $[87,166,167]$. Oxidative modification of LDL is known to be a feature of the atherosclerotic process [168] as Ox-LDL is taken up by macrophages via scavenger receptor pathways to form cholesteryl ester-rich foam cells and endothelial cells become dysfunctional, in part, by taking up Ox-LDL via the lectin-like oxidized LDL receptor-1 [169]. The presence of Ox-LDL has been confirmed in atherosclerotic plaques using immunohistochemical staining for modified apolipoprotein B-100, the protein moiety in LDL [170]. Because the formation of Ox-LDL produces many immunogenic epitopes, it has been possible to detect the presence of Ox-LDL via immunoassays of plasma or circulating plasma auto-antibodies. Several clinical studies (Table 3) revealed that elevated Ox-LDL, auto-antibodies against Ox-LDL or malondialdehyde modified LDL particles are strongly associated with atherosclerosis and CAD including acute coronary syndrome [171177]. In healthy individuals, circulating levels of Ox-LDL are independent predictors of atherosclerosis detected by ultrasound techniques or the occurrence of clinical CAD [178, 
179]. Based upon this literature, Ox-LDL levels have been proposed as a biomarker of CVD risk beyond LDL-cholesterol concentrations [179]. However, more information is needed about how Ox-LDL compares to other, more established, biomarkers of CVD activity before one can conclude with confidence the ultimate utility of Ox-LDL levels in predicting atherosclerosis disease activity.

\section{MPO}

MPO can be measured in both inflammatory cells and as a circulating enzyme and it is known to participate in both atherosclerosis and its clinical sequelae. In human atherosclerotic lesions, MPO and hypochlorite-modified proteins are co-localized [144, 180]. Macrophages in eroded or ruptured plaques are rich in MPO compared to macrophages in fatty streaks that contain little MPO [181]. These data suggest that MPO predicts the clinical activity of atherosclerosis and there is data that tests this prediction (Table 3). Indeed, in human study participants, there is a strong inverse association between MPO serum concentrations and brachial artery flow-mediated dilation, another predictor for the clinical activity of atherosclerosis [182]. As one might expect, this enzyme has been the subject of a number of epidemiological studies across a wide range of patient populations that clearly indicate MPO is an important risk marker for CAD, even in patients with unstable angina and MI $[155,156,158,183-191]$. If one accepts the notion that MPO is associated with atherosclerosis-related CVD, it follows that reduced MPO levels should predict a lower occurrence of CVD. Indeed, epidemiological studies have indicated that individuals with total or near total deficiency of MPO are less likely to develop CAD [154]. Individuals who have specific MPO gene promoter polymorphism that decrease MPO expression have reduced CAD manifestations, whereas subjects with polymorphisms increasing MPO expression exhibit increased CAD [192, 193]. Thus, there is ample evidence that measurements of MPO in humans provide important information about the likelihood of CAD and its clinical sequelae.

Although the data outlined above provide a compelling case for MPO in the clinical prediction of atherosclerosis, there are a few caveats that bear mention. For example, MPO mass is typically measured in the clinical studies, whereas its activity has not been well studied. It is also important to note that specific cut-off values for MPO levels have not been firmly established. The relative merits of different types of analytical specimens also remains to be established as plasma MPO levels are sensitive to heparin dosing [194, 195], neutrophil activation [196], and the method of collection [197]. Thus, before MPO can be used routinely in clinical practice for CVD risk stratification, there will need to be considerable standardization of its sampling.

\section{Plasma F2-isoprostanes}

The F2-isoprostanes are a non-enzymatically generated oxidative products of arachidonic acid that may be derived from esterified fatty acid sources such as membrane phospholipids [198] or circulating LDL [199, 200]. Once formed, these compounds may circulate as the free form, or remain esterified in phospholipids and may be found in both plasma and in urine [201, 202]. Because F2 isoprostanes are structurally stable end products in vivo, they are cumulative and serve as good markers of oxidative stress [203]. The reliability of isoprostanes as in vivo markers of lipid peroxidation makes them an effective method of quantifying both ROS impact and the biologic activity of antioxidants [204].

The production of F2-isoprostanes can occur through the action of several cell types known to be involved in atherosclerosis including monocytes [205] and these oxidation products have been localized within foam cells and atherosclerotic plaques in human specimen [206, 207]. Consistent with this production of isoprostanes during atherosclerosis, several clinical 
studies have established a link between CAD and isoprostane levels (Table 3). Elevated levels of plasma F2-isoprostanes is associated with the extent and the severity of CAD [208]. Increased levels of urinary isoprostanes are a sensitive and independent risk marker of CAD and are known to be increased in patients with unstable angina $[209,210]$ and free F2isoprostane and choline levels are useful prognostic indicators of future (30 day) cardiac events [211]. Isoprostanes also appear to be reliable markers of ischemic tissue injury. For example, increased levels of F2-isoprostanes have been noted after ischemia/reperfusion induced by percutaneous coronary intervention [212]. Furthermore, Pericardial levels of F2isoprostanes increase with the functional severity of congestive heart failure and are associated with pathologic cardiac remodeling [213]. Plasma levels of F2-isoprostanes are also increased in patients with chronic heart failure in relation to disease severity and the degree of cardiac dysfunction [214].

The data outlined above suggest that F2-isoprostanes could be used as a clinical tool for the prediction of cardiovascular events. However, before any biomarker can be used clinically, there are certain requirements that must be met [215] and one of these criteria is the ease of assay performance. Until the performance of isoprostanes is relatively facile and reproducible in non-expert hands, it is unlikely they will serve as a clinical tool. Moreover, few studies to date with isoprostanes have been sufficiently diverse to ensure that any findings with this biomarker are broadly applicable. Thus, there is considerable work that still needs to be done before the clinical utility of isoprostanes is secured.

\section{Other specific measures of oxidative damage}

In addition to those outlined above, there are other measures of ROS action that have been applied to clinical populations as biomarkers of CVD (Table 3). On those whole, these biomarkers are less mature in their development and, as a consequence, have less literature supporting their use. For example, lower plasma concentration of ascorbic acid (a well known endogenous antioxidant) predict the presence of an unstable coronary syndrome [216]. Bilirubin is an effective antioxidant [217] and has been consistently shown to be inversely related to CVD [218-220]. There are now several reports indicating that urinary levels of biopyrrins, oxidative metabolites of bilirubin, may be useful in predicting subsequent cardiac events after reperfusion in acute $\mathrm{MI}$ and that biopyrrins are elevated in heart failure [221, 222]. The cellular antioxidant enzyme, glutathione peroxidase-1 (GPX-1) activity was decreased in CAD patients and lower GPX-1 activity predicted the incidence of cardiovascular events at five years [223]. Cellular DNA is a target of ROS-mediated damage and 8 hydroxyl-2'-deoxyguanosine is a well-characterized product of DNA damage. The urinary levels of 8 hydroxyl-2'-deoxyguanosine in acute MI have been used to predict subsequent cardiac events [224] and patients with dilated cardiomyopathy exhibited significantly elevated serum levels of 8 hydroxyl-2'-deoxyguanosine compared with control subjects [225].

In considering new biomarkers as tools for predicting CVD, it is important to realize there is already a rich literature in cardiovascular risk prediction. We know that LDL cholesterol, HDL cholesterol, smoking, diabetes, advancing age, and hypertension are all informative with regards to an individual patient's risk of developing the two major manifestations of CVD, heart attack and stroke. Moreover, there are numerous scoring systems used for risk prediction that quantify the individual contributions of the risk factors outlined above. Thus, it is rather difficult for any one (oxidative stress) biomarker to add significant information to these existing risk prediction models. Nevertheless, the development of oxidative stress biomarkers has helped establish that ROS and oxidative events are part of the pathophysiology of CVD. It remains to be seen if consideration of these ROS-sensitive biomarkers can add clinically important information to patient care [226]. 


\section{Studies of ROS involving the myocardium}

In addition to the vascular component of cardiovascular disease, considerable morbidity and mortality also results from pathology in the myocardium related to ischemia/reperfusion injury and heart failure. The former being an important manifestation of heart attack and stroke, whereas the latter is a consequence of poor myocardial function. Thus, there have been attempts to determine the impact of ROS on the heart directly. In the paragraphs below, we will focus on studies that have provided insight into how ROS impact heart function independent from events in the vasculature.

\section{Ischemic reperfusion injury, arrhythmia and infarction}

Since MI involves interruption of the blood flow to the myocardium, contemporary therapies for MI include using mechanical (balloon angioplasty) and pharmacological (thrombolysis) strategies to restore blood flow. It has long been known that restoration of blood flow affords the recruitment of inflammatory cells and the activation of cellular injury responses that can produce additional cardiac damage and complications, a process known as reperfusion injury [227-229]. This injury can be manifest as dysfunction and/or death of myocardial and vascular tissue. Moreover, myocardial damage can also produce dysfunction of the cardiac electrical system leading to arrhythmias. The pathophysiology of reperfusion injury has been linked to changes in energy balance, cellular architecture, and the activity of leukocytes, platelets, and the complement system. Also among the features of reperfusion injury is a burst of free radical formation that may continue for hours [230] and has been attributed to multiple sources including xanthine oxidase, activated neutrophils, electron leakage from mitochondria, catecholamine oxidation, cyclooxygenase and lipoxygenase [231]. This increased ROS flux has been shown to damage myocytes, impair contractile function, and contribute to capillary leakage [231,232]. Thus, there is considerable evidence that reperfusion-induced ROS production can contribute to cardiac pathology. As a consequence of the evidence outlined above, there has been investigation into the implications of suppressing the ROS flux associated with reperfusion injury.

One strategy for mitigating ROS-dependent reperfusion injury relates to the release of free iron, an element known to be released from tissues during ischemia and reperfusion [233]. Free iron supports the oxidation of lipids [234, 235], particularly in the presence of ROS [236]. Moreover, metal-catalyzed oxidation reactions have been linked to cardiac dysfunction during ischemia and reperfusion [233]. Thus, it not surprising that metal chelation has been tested as an antioxidant strategy in preventing ischemia/reperfusion injury. Treatment with the iron chelator, deferoxamine, has been shown to limit reperfusion injury [237] and reoxygenation-induced myocyte death [238]. Consistent with these findings, clinical trials of deferoxamine in cardiac bypass patients show reduced myocyte necrosis [239] and improved cardiac function [240]. Thus, iron chelation limits reperfusion injury in the clinical setting, supporting the notion that ROS are important for cardiac reperfusion injury.

One agent that deserves mention is edaravone. This compound prevents lipid peroxidation and is thought to function via free radical scavenging [241]. There have been two small studies examining this agent before reperfusion in patients with acute MI that demonstrated decreased incidence of reperfusion arrhythmia and reduced cardiovascular events in long term follow-up [242, 243]. Consistent with this activity, edaravone is now approved in Japan for the treatment of acute ischemic stroke [241]. It is important to realize, however, that the trials in the heart have been of a small scale and without blinding. Therefore, more data will be needed before this agent, currently unavailable in the US, can be recommended as a treatment for reperfusion injury. 
Another interesting therapeutic strategy is the use of high oxygen tensions that can diminish reperfusion injury [244]. It is though the effect is mediated, in part, by reducing the formation of lipid peroxide radicals [245]. This concept was evaluated in two clinical trials $[246,247]$ and the results demonstrated that supersaturated oxygen therapy was associated with a reduction in infarct size.

There are a number of therapeutic challenges in devising strategies to prevent reperfusion injury and many of these have been outlined in excellent reviews [248, 249]. In brief, challenges lie in the multiple mechanisms that contribute to the consequences of MI and reperfusion injury and it is naïve to believe any one strategy can target all of these mechanisms. Moreover, it is exceedingly difficult to target ROS-mediated events in vivo, particularly if they are occurring within the cell. Moreover, the therapeutic window is extremely narrow. Most agents are very effective when administered before the injury and their efficacy diminishes as a function of time after injury. In the clinical realm, we rarely have the luxury of knowing when a patient is likely to suffer an MI or ischemic stroke, so pre-injury administration is unlikely. Nevertheless, as we develop a more thorough understanding of the mechanisms related to reperfusion injury, we may come upon the requisite knowledge needed to design new therapies that are not as time sensitive with respect to the ischemic insult.

\section{Myocardial hypertrophy, cardiomyopathy and heart failure}

Space constraints preclude a detailed discussion of the pathophysiology of heart failure here, but it is a term used to describe the syndrome that results from poor contractile function of the left ventricle, the cardiac chamber responsible for pumping blood into the systemic circulation. Upon the failure of the left ventricle, the heart filling pressures increase (i.e. congestion) and patients develop symptoms of breathlessness. Poor cardiac performance also leaves vital organs underperfused. We know from many years of study, that heart failure involves not only some acute injury to the myocardium (e.g. infarct, genetic abnormality, pressure overload from hypertension, etc.), but also a maladaptive healing process that can exacerbate the injury. There is evidence for oxidative stress in all of these facets of heart failure development [250, 251]. It is clear ROS may contribute to myocyte injury resulting from ischemic reperfusion injury (as above) [252], anthracycline cardiotoxicity [253], reduction of endogenous antioxidants in the myocardium [254-258], and the remodeling response [259]. For example, mice over expressing the endogenous antioxidant enzyme glutathione peroxidase are protected against LV dilation, dysfunction, and death after MI [260]. Overexpression of heme oxygenase-1, an antioxidant enzyme that metabolizes heme and has anti-apoptotic effects, prevented pathologic LV remodeling with decreasing oxidative stress in an MI model [261]. Antioxidant therapies for heart failure in animal models also suggest a benefit from reduced generation of free radicals that: i) limits myocyte damage [262]; ii) improves cardiac function after reperfusion [263, 264]; iii) attenuate remodeling and cardiomyopathy [265-270].

There are several biomarkers that also specifically support the increase of oxidative stress in patients with heart failure (please see table 3) [211, 213, 214, 222]. NADPH oxidase activity in myocardium is increased in the failing human hearts [271] and electroparamagnetic resonance studies with spin trapping directly demonstrate an increased levels of $\mathrm{O}_{2}{ }^{--}$in human failing hearts [272]. Serum uric acid levels are increased as a function of heart failure disease severity, and independently predict survival in chronic heart failure patients [273]. The uric acid levels are thought to reflect, in part, xanthine oxidase activation and this may also predict the incidence of heart failure [274]. Consistent with this contention, xanthine oxidase activity in the myocardium is increased in patients with chronic mitral regurgitation with normal LV function and may contribute to myofibrillar degeneration and contractile dysfunction [275]. 
The finding that xanthine oxidase activity may be increased in the setting of heart failure has prompted additional studies. Intracoronary infusion of allopurinol, a xanthine oxidase inhibitor, increases myocardial efficiency in heart failure patients [276] and systemic allopurinol reduces markers of oxidative stress and improves endothelial function in patients diagnosed with heart failure [277], independent of serum uric acid levels [278]. While these small scale studies demonstrate that xanthine oxidase contributes to some elements of heart failure physiology (e.g. endothelial dysfunction and impaired myocardial efficiency), they do not tell us if these effects translate into improved patient outcomes. To address this issue, 405 patients were enrolled in a randomized, multicenter trial (OPT-CHF) of oxypurinol in the treatment of heart failure [279]. Oxypurinol, a drug similar to allopurinol, did not have any impact on heart failure morbidity, mortality, or quality of life in that study [279]. The most obvious explanation is that xanthine oxidase, while contributing to some aspects of heart failure physiology, does not contribute to the clinical outcome of patients. Other possible reasons for the discrepancy between physiologic and outcome studies are: a) differences between allopurinol and oxypurinol; $b$ ) the fact that the OPT-CHF dose of oxypurinol is only equivalent to a low dose of allopurinol [280]; and c) that many more patients might be needed to detect clinical outcome differences compared to the modest number of patients needed to detect physiologic changes to xanthine oxidase inhibition.

\section{Conclusion}

Overall, there are considerable data linking oxidative stress and ROS to the physiology and pathophysiology of CVD. Initial attempts to ameliorate manifestations of CVD with simple antioxidant strategies have not proven helpful, likely because ROS have important and diverse physiological roles. As our understanding of how the source(s) of ROS are regulated and how specific ROS interact with their target(s), we have developed a greater understanding of how ROS modulate cardiovascular pathophysiology. It seems clear that our ability to impact distinct ROS-sensitive pathways will require even more understanding of the specific molecular targets and effective therapeutic strategies will likely exploit factors that dictate ROS specificity.

\section{Acknowledgments}

This study was supported by NIH grants HL092122, HL098407, HL 081587 and the Diabetes Endocrinology Research Center grant DK32520. Dr. Sugamura is supported by Japan Heart Foundation / Bayer Yakuhin Research Grant Abroad (2009) and the Uehara Memorial Foundation Research Fellowship (2010), Japan.

\section{List of Abbreviations}

$\begin{array}{ll}\text { 5-LO } & \text { 5-lipoxygenase } \\ \text { 5-MTHF } & \text { 5-methyl tetrahydrofolate } \\ \text { 12-LO } & \text { 12-lipoxygenase } \\ \text { 12/15-LO } & \text { 12/15-lipoxygenase } \\ \text { AII } & \text { angiotensin II } \\ \text { AAA } & \text { abdominal aortic aneurysm } \\ \text { ACS } & \text { acute coronary syndrome } \\ \text { Apo A-I } & \text { apolipoprotein A-I } \\ \text { ApoE } & \text { apolipoprotein E } \\ \text { AV } & \text { atrio-ventricular }\end{array}$




\begin{tabular}{|c|c|}
\hline $\mathrm{BH}_{4}$ & 5,6,7,8-tetrahydrobiopterin \\
\hline CAD & coronary artery disease \\
\hline CHD & coronary heart disease \\
\hline CVD & cardiovascular disease \\
\hline DCM & dilated cardiomyopathy \\
\hline eNOS & endothelial nitric oxide synthase \\
\hline GCH & GTP-cyclohydrolase \\
\hline GPX-1 & glutathione peroxidase- 1 \\
\hline HDL & high density lipoprotein \\
\hline $\mathbf{H F}$ & heart failure \\
\hline iNOS & inducible nitric oxide synthase \\
\hline LDL & low density lipoprotein \\
\hline LDL-R & low density lipoprotein receptor \\
\hline $\mathbf{L V}$ & left ventricular \\
\hline MI & myocardial infarction \\
\hline Mn-SOD & manganese superoxide dismutase \\
\hline MPO & myeloperoxidase \\
\hline NADPH & nicotinamide adenine dinucleotide phosphate \\
\hline nNOS & neuronal nitric oxide synthase \\
\hline NO & nitric oxide \\
\hline NOS & nitric oxide synthase \\
\hline Ox-LDL & oxidized low density lipoprotein \\
\hline PC & preconditioning \\
\hline PROBE & prospective randomized open blinded end-point \\
\hline $\mathbf{R C T}$ & randomized controlled trial \\
\hline ROS & reactive oxygen species \\
\hline TAC & transverse aortic constriction \\
\hline
\end{tabular}

\section{References}

1. Harman D. Aging: a theory based on free radical and radiation chemistry. J Gerontol. 1956; 11:298300. [PubMed: 13332224]

2. Enstrom JE, Kanim LE, Klein MA. Vitamin C intake and mortality among a sample of the United States population. Epidemiology. 1992; 3:194-202. [PubMed: 1591317]

3. Khaw KT, Bingham S, Welch A, Luben R, Wareham N, Oakes S, Day N. Relation between plasma ascorbic acid and mortality in men and women in EPIC-Norfolk prospective study: a prospective population study. European Prospective Investigation into Cancer and Nutrition. Lancet. 2001; 357:657-663. [PubMed: 11247548]

4. Nyyssonen K, Parviainen MT, Salonen R, Tuomilehto J, Salonen JT. Vitamin C deficiency and risk of myocardial infarction: prospective population study of men from eastern Finland. Bmj. 1997; 314:634-638. [PubMed: 9066474] 
5. Osganian SK, Stampfer MJ, Rimm E, Spiegelman D, Hu FB, Manson JE, Willett WC. Vitamin C and risk of coronary heart disease in women. J Am Coll Cardiol. 2003; 42:246-252. [PubMed: 12875759]

6. Stampfer MJ, Hennekens CH, Manson JE, Colditz GA, Rosner B, Willett WC. Vitamin E consumption and the risk of coronary disease in women. N Engl J Med. 1993; 328:1444-1449. [PubMed: 8479463]

7. Rimm EB, Stampfer MJ, Ascherio A, Giovannucci E, Colditz GA, Willett WC. Vitamin E consumption and the risk of coronary heart disease in men. N Engl J Med. 1993; 328:1450-1456. [PubMed: 8479464]

8. Gale CR, Martyn CN, Winter PD, Cooper C. Vitamin C and risk of death from stroke and coronary heart disease in cohort of elderly people. Bmj. 1995; 310:1563-1566. [PubMed: 7787644]

9. MRC/BHF Heart Protection Study of antioxidant vitamin supplementation in 20,536 high-risk individuals: a randomised placebo-controlled trial. Lancet. 2002; 360:23-33. [PubMed: 12114037]

10. Sesso HD, Buring JE, Christen WG, Kurth T, Belanger C, MacFadyen J, Bubes V, Manson JE, Glynn RJ, Gaziano JM. Vitamins E and C in the prevention of cardiovascular disease in men: the Physicians' Health Study II randomized controlled trial. Jama. 2008; 300:2123-2133. [PubMed: 18997197]

11. Kushi LH, Folsom AR, Prineas RJ, Mink PJ, Wu Y, Bostick RM. Dietary antioxidant vitamins and death from coronary heart disease in postmenopausal women. N Engl J Med. 1996; 334:11561162. [PubMed: 8602181]

12. Losonczy KG, Harris TB, Havlik RJ. Vitamin E and vitamin C supplement use and risk of allcause and coronary heart disease mortality in older persons: the Established Populations for Epidemiologic Studies of the Elderly. Am J Clin Nutr. 1996; 64:190-196. [PubMed: 8694019]

13. Virtamo J, Rapola JM, Ripatti S, Heinonen OP, Taylor PR, Albanes D, Huttunen JK. Effect of vitamin $\mathrm{E}$ and beta carotene on the incidence of primary nonfatal myocardial infarction and fatal coronary heart disease. Arch Intern Med. 1998; 158:668-675. [PubMed: 9521232]

14. de Gaetano G. Low-dose aspirin and vitamin $\mathrm{E}$ in people at cardiovascular risk: a randomised trial in general practice. Collaborative Group of the Primary Prevention Project. Lancet. 2001; 357:8995. [PubMed: 11197445]

15. Lee IM, Cook NR, Gaziano JM, Gordon D, Ridker PM, Manson JE, Hennekens CH, Buring JE. Vitamin $\mathrm{E}$ in the primary prevention of cardiovascular disease and cancer: the Women's Health Study: a randomized controlled trial. Jama. 2005; 294:56-65. [PubMed: 15998891]

16. Yusuf S, Dagenais G, Pogue J, Bosch J, Sleight P. Vitamin E supplementation and cardiovascular events in high-risk patients. The Heart Outcomes Prevention Evaluation Study Investigators. N Engl J Med. 2000; 342:154-160. [PubMed: 10639540]

17. Lonn E, Bosch J, Yusuf S, Sheridan P, Pogue J, Arnold JM, Ross C, Arnold A, Sleight P, Probstfield J, Dagenais GR. Effects of long-term vitamin E supplementation on cardiovascular events and cancer: a randomized controlled trial. Jama. 2005; 293:1338-1347. [PubMed: 15769967]

18. Omenn GS, Goodman GE, Thornquist MD, Balmes J, Cullen MR, Glass A, Keogh JP, Meyskens FL, Valanis B, Williams JH, Barnhart S, Hammar S. Effects of a combination of beta carotene and vitamin A on lung cancer and cardiovascular disease. N Engl J Med. 1996; 334:1150-1155. [PubMed: 8602180]

19. Hennekens CH, Buring JE, Manson JE, Stampfer M, Rosner B, Cook NR, Belanger C, LaMotte F, Gaziano JM, Ridker PM, Willett W, Peto R. Lack of effect of long-term supplementation with beta carotene on the incidence of malignant neoplasms and cardiovascular disease. N Engl J Med. 1996; 334:1145-1149. [PubMed: 8602179]

20. Lee IM, Cook NR, Manson JE, Buring JE, Hennekens CH. Beta-carotene supplementation and incidence of cancer and cardiovascular disease: the Women's Health Study. J Natl Cancer Inst. 1999; 91:2102-2106. [PubMed: 10601381]

21. Waters DD, Alderman EL, Hsia J, Howard BV, Cobb FR, Rogers WJ, Ouyang P, Thompson P, Tardif JC, Higginson L, Bittner V, Steffes M, Gordon DJ, Proschan M, Younes N, Verter JI. Effects of hormone replacement therapy and antioxidant vitamin supplements on coronary 
atherosclerosis in postmenopausal women: a randomized controlled trial. Jama. 2002; 288:24322440. [PubMed: 12435256]

22. Cook NR, Albert CM, Gaziano JM, Zaharris E, MacFadyen J, Danielson E, Buring JE, Manson JE. A randomized factorial trial of vitamins $\mathrm{C}$ and $\mathrm{E}$ and beta carotene in the secondary prevention of cardiovascular events in women: results from the Women's Antioxidant Cardiovascular Study. Arch Intern Med. 2007; 167:1610-1618. [PubMed: 17698683]

23. Stephens NG, Parsons A, Schofield PM, Kelly F, Cheeseman K, Mitchinson MJ. Randomised controlled trial of vitamin $\mathrm{E}$ in patients with coronary disease: Cambridge Heart Antioxidant Study (CHAOS). Lancet. 1996; 347:781-786. [PubMed: 8622332]

24. Boaz M, Smetana S, Weinstein T, Matas Z, Gafter U, Iaina A, Knecht A, Weissgarten Y, Brunner D, Fainaru M, Green MS. Secondary prevention with antioxidants of cardiovascular disease in endstage renal disease (SPACE): randomised placebo-controlled trial. Lancet. 2000; 356:12131218. [PubMed: 11072938]

25. Dietary supplementation with n-3 polyunsaturated fatty acids and vitamin $\mathrm{E}$ after myocardial infarction: results of the GISSI-Prevenzione trial. Gruppo Italiano per lo Studio della Sopravvivenza nell'Infarto miocardico. Lancet. 1999; 354:447-455. [PubMed: 10465168]

26. Rapola JM, Virtamo J, Ripatti S, Haukka JK, Huttunen JK, Albanes D, Taylor PR, Heinonen OP. Effects of alpha tocopherol and beta carotene supplements on symptoms, progression, and prognosis of angina pectoris. Heart. 1998; 79:454-458. [PubMed: 9659191]

27. Rapola JM, Virtamo J, Ripatti S, Huttunen JK, Albanes D, Taylor PR, Heinonen OP. Randomised trial of alpha-tocopherol and beta-carotene supplements on incidence of major coronary events in men with previous myocardial infarction. Lancet. 1997; 349:1715-1720. [PubMed: 9193380]

28. Vivekananthan DP, Penn MS, Sapp SK, Hsu A, Topol EJ. Use of antioxidant vitamins for the prevention of cardiovascular disease: meta-analysis of randomised trials. Lancet. 2003; 361:20172023. [PubMed: 12814711]

29. Anderson TJ, Meredith IT, Yeung AC, Frei B, Selwyn AP, Ganz P. The effect of cholesterollowering and antioxidant therapy on endothelium-dependent coronary vasomotion. N Engl J Med. 1995; 332:488-493. [PubMed: 7830729]

30. Keaney JF Jr, Xu A, Cunningham D, Jackson T, Frei B, Vita JA. Dietary probucol preserves endothelial function in cholesterol-fed rabbits by limiting vascular oxidative stress and superoxide generation. J Clin Invest. 1995; 95:2520-2529. [PubMed: 7769097]

31. Parthasarathy S, Young SG, Witztum JL, Pittman RC, Steinberg D. Probucol inhibits oxidative modification of low density lipoprotein. J Clin Invest. 1986; 77:641-644. [PubMed: 3944273]

32. Tardif JC, Cote G, Lesperance J, Bourassa M, Lambert J, Doucet S, Bilodeau L, Nattel S, de Guise P. Probucol and multivitamins in the prevention of restenosis after coronary angioplasty. Multivitamins and Probucol Study Group. N Engl J Med. 1997; 337:365-372. [PubMed: 9241125]

33. Daida H, Kuwabara Y, Yokoi H, Nishikawa H, Takatsu F, Nakata Y, Kutsumi Y, Oshima S, Nishiyama S, Ishiwata S, Kato K, Nishimura S, Miyauchi K, Kanoh T, Yamaguchi H. Effect of probucol on repeat revascularization rate after percutaneous transluminal coronary angioplasty (from the Probucol Angioplasty Restenosis Trial [PART]). Am J Cardiol. 2000; 86:550-552. [PubMed: 11009277]

34. Yokoi H, Daida H, Kuwabara Y, Nishikawa H, Takatsu F, Tomihara H, Nakata Y, Kutsumi Y, Ohshima S, Nishiyama S, Seki A, Kato K, Nishimura S, Kanoh T, Yamaguchi H. Effectiveness of an antioxidant in preventing restenosis after percutaneous transluminal coronary angioplasty: the Probucol Angioplasty Restenosis Trial. J Am Coll Cardiol. 1997; 30:855-862. [PubMed: 9316509]

35. Walldius F, Erikson U, Olsson AG, Bergstrand L, Hadell K, Johansson J, Kaijser L, Lassvik C, Molgaard J, Nillson S. The effect of probucol on femoral atherosclerosis: the Probucol Quantitative Regression Swedish Trial (PQRST). American Journal of Cardiology. 1994; 74:875883. [PubMed: 7977117]

36. Parthasarathy S. Evidence for an additional intracellular site of action of probucol in the prevention of oxidative modification of low density lipoprotein. Use of a new water-soluble probucol derivative. The Journal of Clinical Investigation. 1992; 89:1618-1621. [PubMed: 1569200] 
37. Tardif JC, McMurray JJ, Klug E, Small R, Schumi J, Choi J, Cooper J, Scott R, Lewis EF, L'Allier PL, Pfeffer MA. Effects of succinobucol (AGI-1067) after an acute coronary syndrome: a randomised, double-blind, placebo-controlled trial. Lancet. 2008; 371:1761-1768. [PubMed: 18502300]

38. Halliwell B, Rafter J, Jenner A. Health promotion by flavonoids, tocopherols, tocotrienols, and other phenols: direct or indirect effects? Antioxidant or not? Am J Clin Nutr. 2005; 81:268S-276S. [PubMed: 15640490]

39. Traber MG, Frei B, Beckman JS. Vitamin E revisited: do new data validate benefits for chronic disease prevention? Curr Opin Lipidol. 2008; 19:30-38. [PubMed: 18196984]

40. Steinberg D. The LDL modification hypothesis of atherogenesis: an update. J Lipid Res. 2009; 50(Suppl):S376-381. [PubMed: 19011257]

41. Halliwell B. The wanderings of a free radical. Free Radic Biol Med. 2009; 46:531-542. [PubMed: 19111608]

42. Milman U, Blum S, Shapira C, Aronson D, Miller-Lotan R, Anbinder Y, Alshiek J, Bennett L, Kostenko M, Landau M, Keidar S, Levy Y, Khemlin A, Radan A, Levy AP. Vitamin E supplementation reduces cardiovascular events in a subgroup of middle-aged individuals with both type 2 diabetes mellitus and the haptoglobin 2-2 genotype: a prospective double-blinded clinical trial. Arterioscler Thromb Vasc Biol. 2008; 28:341-347. [PubMed: 18032779]

43. Zingg JM, Azzi A, Meydani M. Genetic polymorphisms as determinants for disease-preventive effects of vitamin E. Nutr Rev. 2008; 66:406-414. [PubMed: 18667016]

44. Leopold JA, Loscalzo J. Oxidative enzymopathies and vascular disease. Arterioscler Thromb Vasc Biol. 2005; 25:1332-1340. [PubMed: 15790928]

45. Keaney JF Jr, Larson MG, Vasan RS, Wilson PW, Lipinska I, Corey D, Massaro JM, Sutherland P, Vita JA, Benjamin EJ. Obesity and systemic oxidative stress: clinical correlates of oxidative stress in the Framingham Study. Arterioscler Thromb Vasc Biol. 2003; 23:434-439. [PubMed: 12615693]

46. Finkel T, Holbrook NJ. Oxidants, oxidative stress and the biology of ageing. Nature. 2000; 408:239-247. [PubMed: 11089981]

47. Stocker R, Keaney JF Jr. Role of oxidative modifications in atherosclerosis. Physiol Rev. 2004; 84:1381-1478. [PubMed: 15383655]

48. Chance B, Sies H, Boveris A. Hydroperoxide metabolism in mammalian organs. Physiol Rev. 1979; 59:527-605. [PubMed: 37532]

49. Li Y, Huang TT, Carlson EJ, Melov S, Ursell PC, Olson JL, Noble LJ, Yoshimura MP, Berger C, Chan PH, Wallace DC, Epstein CJ. Dilated cardiomyopathy and neonatal lethality in mutant mice lacking manganese superoxide dismutase. Nat Genet. 1995; 11:376-381. [PubMed: 7493016]

50. Nojiri H, Shimizu T, Funakoshi M, Yamaguchi O, Zhou H, Kawakami S, Ohta Y, Sami M, Tachibana T, Ishikawa H, Kurosawa H, Kahn RC, Otsu K, Shirasawa T. Oxidative stress causes heart failure with impaired mitochondrial respiration. J Biol Chem. 2006; 281:33789-33801. [PubMed: 16959785]

51. Matsushima S, Ide T, Yamato M, Matsusaka H, Hattori F, Ikeuchi M, Kubota T, Sunagawa K, Hasegawa Y, Kurihara T, Oikawa S, Kinugawa S, Tsutsui H. Overexpression of mitochondrial peroxiredoxin-3 prevents left ventricular remodeling and failure after myocardial infarction in mice. Circulation. 2006; 113:1779-1786. [PubMed: 16585391]

52. Bedard K, Krause KH. The NOX family of ROS-generating NADPH oxidases: physiology and pathophysiology. Physiol Rev. 2007; 87:245-313. [PubMed: 17237347]

53. Chen K, Craige SE, Keaney JF Jr. Downstream targets and intracellular compartmentalization in Nox signaling. Antioxid Redox Signal. 2009; 11:2467-2480. [PubMed: 19309256]

54. Johar S, Cave AC, Narayanapanicker A, Grieve DJ, Shah AM. Aldosterone mediates angiotensin II-induced interstitial cardiac fibrosis via a Nox2-containing NADPH oxidase. Faseb J. 2006; 20:1546-1548. [PubMed: 16720735]

55. Bell RM, Cave AC, Johar S, Hearse DJ, Shah AM, Shattock MJ. Pivotal role of NOX-2-containing NADPH oxidase in early ischemic preconditioning. Faseb J. 2005; 19:2037-2039. [PubMed: 16236999] 
56. Looi YH, Grieve DJ, Siva A, Walker SJ, Anilkumar N, Cave AC, Marber M, Monaghan MJ, Shah AM. Involvement of Nox2 NADPH oxidase in adverse cardiac remodeling after myocardial infarction. Hypertension. 2008; 51:319-325. [PubMed: 18180403]

57. Satoh M, Ogita H, Takeshita K, Mukai Y, Kwiatkowski DJ, Liao JK. Requirement of Rac1 in the development of cardiac hypertrophy. Proc Natl Acad Sci U S A. 2006; 103:7432-7437. [PubMed: 16651530]

58. Byrne JA, Grieve DJ, Bendall JK, Li JM, Gove C, Lambeth JD, Cave AC, Shah AM. Contrasting roles of NADPH oxidase isoforms in pressure-overload versus angiotensin II-induced cardiac hypertrophy. Circ Res. 2003; 93:802-805. [PubMed: 14551238]

59. Bendall JK, Cave AC, Heymes C, Gall N, Shah AM. Pivotal role of a gp91(phox)-containing NADPH oxidase in angiotensin II-induced cardiac hypertrophy in mice. Circulation. 2002; 105:293-296. [PubMed: 11804982]

60. Maytin M, Siwik DA, Ito M, Xiao L, Sawyer DB, Liao R, Colucci WS. Pressure overload-induced myocardial hypertrophy in mice does not require gp91phox. Circulation. 2004; 109:1168-1171. [PubMed: 14981002]

61. Barry-Lane PA, Patterson C, van der Merwe M, Hu Z, Holland SM, Yeh ET, Runge MS. p47phox is required for atherosclerotic lesion progression in $\mathrm{ApoE}(-/-)$ mice. J Clin Invest. 2001; 108:15131522. [PubMed: 11714743]

62. Vendrov AE, Hakim ZS, Madamanchi NR, Rojas M, Madamanchi C, Runge MS. Atherosclerosis is attenuated by limiting superoxide generation in both macrophages and vessel wall cells. Arterioscler Thromb Vasc Biol. 2007; 27:2714-2721. [PubMed: 17823367]

63. Judkins CP, Diep H, Broughton BR, Mast AE, Hooker EU, Miller AA, Selemidis S, Dusting GJ, Sobey CG, Drummond GR. Direct evidence of a role for Nox2 in superoxide production, reduced nitric oxide bioavailability, and early atherosclerotic plaque formation in ApoE-/- mice. Am J Physiol Heart Circ Physiol. 2009; 298:H24-32. [PubMed: 19837950]

64. Thomas M, Gavrila D, McCormick ML, Miller FJ Jr, Daugherty A, Cassis LA, Dellsperger KC, Weintraub NL. Deletion of p47phox attenuates angiotensin II-induced abdominal aortic aneurysm formation in apolipoprotein E-deficient mice. Circulation. 2006; 114:404-413. [PubMed: 16864727]

65. Chen Z, Keaney JF Jr, Schulz E, Levison B, Shan L, Sakuma M, Zhang X, Shi C, Hazen SL, Simon DI. Decreased neointimal formation in Nox2-deficient mice reveals a direct role for NADPH oxidase in the response to arterial injury. Proc Natl Acad Sci U S A. 2004; 101:1301413019. [PubMed: 15316118]

66. Ushio-Fukai M. Compartmentalization of redox signaling through NADPH oxidase-derived ROS. Antioxid Redox Signal. 2009; 11:1289-1299. [PubMed: 18999986]

67. Jarasch ED, Grund C, Bruder G, Heid HW, Keenan TW, Franke WW. Localization of xanthine oxidase in mammary-gland epithelium and capillary endothelium. Cell. 1981; 25:67-82. [PubMed: 6895049]

68. Harrison R. Structure and function of xanthine oxidoreductase: where are we now? Free Radic Biol Med. 2002; 33:774-797. [PubMed: 12208366]

69. Della Corte E, Gozzetti G, Novello F, Stirpe F. Properties of the xanthine oxidase from human liver. Biochim Biophys Acta. 1969; 191:164-166. [PubMed: 4309908]

70. Granger DN, Hollwarth ME, Parks DA. Ischemia-reperfusion injury: role of oxygen-derived free radicals. Acta Physiol Scand Suppl. 1986; 548:47-63. [PubMed: 3529822]

71. Granger DN, Rutili G, McCord JM. Superoxide radicals in feline intestinal ischemia. Gastroenterology. 1981; 81:22-29. [PubMed: 6263743]

72. McCord JM. Oxygen-derived free radicals in postischemic tissue injury. N Engl J Med. 1985; 312:159-163. [PubMed: 2981404]

73. Ohtsubo T, Rovira, Starost MF, Liu C, Finkel T. Xanthine oxidoreductase is an endogenous regulator of cyclooxygenase-2. Circ Res. 2004; 95:1118-1124. [PubMed: 15528468]

74. Pacher P, Nivorozhkin A, Szabo C. Therapeutic effects of xanthine oxidase inhibitors: renaissance half a century after the discovery of allopurinol. Pharmacol Rev. 2006; 58:87-114. [PubMed: 16507884] 
75. Schroder K, Vecchione C, Jung O, Schreiber JG, Shiri-Sverdlov R, van Gorp PJ, Busse R, Brandes RP. Xanthine oxidase inhibitor tungsten prevents the development of atherosclerosis in ApoE knockout mice fed a Western-type diet. Free Radic Biol Med. 2006; 41:1353-1360. [PubMed: 17023262]

76. Millar TM, Stevens CR, Benjamin N, Eisenthal R, Harrison R, Blake DR. Xanthine oxidoreductase catalyses the reduction of nitrates and nitrite to nitric oxide under hypoxic conditions. FEBS Lett. 1998; 427:225-228. [PubMed: 9607316]

77. Li H, Samouilov A, Liu X, Zweier JL. Characterization of the magnitude and kinetics of xanthine oxidase-catalyzed nitrate reduction: evaluation of its role in nitrite and nitric oxide generation in anoxic tissues. Biochemistry. 2003; 42:1150-1159. [PubMed: 12549937]

78. Zhang Z, Naughton D, Winyard PG, Benjamin N, Blake DR, Symons MC. Generation of nitric oxide by a nitrite reductase activity of xanthine oxidase: a potential pathway for nitric oxide formation in the absence of nitric oxide synthase activity. Biochem Biophys Res Commun. 1998; 249:767-772. [PubMed: 9731211]

79. Godber BL, Doel JJ, Sapkota GP, Blake DR, Stevens CR, Eisenthal R, Harrison R. Reduction of nitrite to nitric oxide catalyzed by xanthine oxidoreductase. J Biol Chem. 2000; 275:7757-7763. [PubMed: 10713088]

80. McNally JS, Davis ME, Giddens DP, Saha A, Hwang J, Dikalov S, Jo H, Harrison DG. Role of xanthine oxidoreductase and $\mathrm{NAD}(\mathrm{P}) \mathrm{H}$ oxidase in endothelial superoxide production in response to oscillatory shear stress. Am J Physiol Heart Circ Physiol. 2003; 285:H2290-H2297. [PubMed: 12958034]

81. Landmesser U, Spiekermann S, Preuss C, Sorrentino S, Fischer D, Manes C, Mueller M, Drexler $\mathrm{H}$. Angiotensin II induces endothelial xanthine oxidase activation: role for endothelial dysfunction in patients with coronary disease. Arterioscler Thromb Vasc Biol. 2007; 27:943-948. [PubMed: 17234726]

82. Brash AR. Lipoxygenases: occurrence, functions, catalysis, and acquisition of substrate. J Biol Chem. 1999; 274:23679-23682. [PubMed: 10446122]

83. Kuhn N, Heydeck D, Hugou I, Gniwotta C. In vivo action of 15-lipoxygenase in early stages of human atherosclerosis. J Clin Invest. 1997; 99:888. [PubMed: 9062346]

84. Zhao L, Funk CD. Lipoxygenase pathways in atherogenesis. Trends Cardiovasc Med. 2004; 14:191-195. [PubMed: 15261891]

85. Lotzer K, Funk CD, Habenicht AJ. The 5-lipoxygenase pathway in arterial wall biology and atherosclerosis. Biochim Biophys Acta. 2005; 1736:30-37. [PubMed: 16081317]

86. Kuhn H, O’Donnell VB. Inflammation and immune regulation by 12/15-lipoxygenases. Prog Lipid Res. 2006; 45:334-356. [PubMed: 16678271]

87. Cyrus T, Pratico D, Zhao L, Witztum JL, Rader DJ, Rokach J, FitzGerald GA, Funk CD. Absence of 12/15-lipoxygenase expression decreases lipid peroxidation and atherogenesis in apolipoprotein e-deficient mice. Circulation. 2001; 103:2277-2282. [PubMed: 11342477]

88. Cyrus T, Witztum JL, Rader DJ, Tangirala R, Fazio S, Linton MF, Funk CD. Disruption of the 12/15-lipoxygenase gene diminishes atherosclerosis in apo E-deficient mice. J Clin Invest. 1999; 103:1597-1604. [PubMed: 10359569]

89. George J, Afek A, Shaish A, Levkovitz H, Bloom N, Cyrus T, Zhao L, Funk CD, Sigal E, Harats D. 12/15-Lipoxygenase gene disruption attenuates atherogenesis in LDL receptor-deficient mice. Circulation. 2001; 104:1646-1650. [PubMed: 11581143]

90. Mehrabian M, Allayee H, Wong J, Shi W, Wang XP, Shaposhnik Z, Funk CD, Lusis AJ. Identification of 5-lipoxygenase as a major gene contributing to atherosclerosis susceptibility in mice. Circ Res. 2002; 91:120-126. [PubMed: 12142344]

91. Zhao L, Cuff CA, Moss E, Wille U, Cyrus T, Klein EA, Pratico D, Rader DJ, Hunter CA, Pure E, Funk CD. Selective interleukin-12 synthesis defect in 12/15-lipoxygenase-deficient macrophages associated with reduced atherosclerosis in a mouse model of familial hypercholesterolemia. J Biol Chem. 2002; 277:35350-35356. [PubMed: 12122008]

92. Bolick DT, Orr AW, Whetzel A, Srinivasan S, Hatley ME, Schwartz MA, Hedrick CC. 12/15lipoxygenase regulates intercellular adhesion molecule-1 expression and monocyte adhesion to 
endothelium through activation of RhoA and nuclear factor-kappaB. Arterioscler Thromb Vasc Biol. 2005; 25:2301-2307. [PubMed: 16166569]

93. Reilly KB, Srinivasan S, Hatley ME, Patricia MK, Lannigan J, Bolick DT, Vandenhoff G, Pei H, Natarajan R, Nadler JL, Hedrick CC. 12/15-Lipoxygenase activity mediates inflammatory monocyte/endothelial interactions and atherosclerosis in vivo. J Biol Chem. 2004; 279:9440-9450. [PubMed: 14676201]

94. Bolick DT, Srinivasan S, Whetzel A, Fuller LC, Hedrick CC. 12/15 lipoxygenase mediates monocyte adhesion to aortic endothelium in apolipoprotein E-deficient mice through activation of RhoA and NF-kappaB. Arterioscler Thromb Vasc Biol. 2006; 26:1260-1266. [PubMed: 16543492]

95. Dwyer JH, Allayee H, Dwyer KM, Fan J, Wu H, Mar R, Lusis AJ, Mehrabian M. Arachidonate 5lipoxygenase promoter genotype, dietary arachidonic acid, and atherosclerosis. N Engl J Med. 2004; 350:29-37. [PubMed: 14702425]

96. Spanbroek R, Grabner R, Lotzer K, Hildner M, Urbach A, Ruhling K, Moos MP, Kaiser B, Cohnert TU, Wahlers T, Zieske A, Plenz G, Robenek H, Salbach P, Kuhn H, Radmark O, Samuelsson B, Habenicht AJ. Expanding expression of the 5-lipoxygenase pathway within the arterial wall during human atherogenesis. Proc Natl Acad Sci U S A. 2003; 100:1238-1243. [PubMed: 12552108]

97. Cipollone F, Mezzetti A, Fazia ML, Cuccurullo C, Iezzi A, Ucchino S, Spigonardo F, Bucci M, Cuccurullo F, Prescott SM, Stafforini DM. Association between 5-lipoxygenase expression and plaque instability in humans. Arterioscler Thromb Vasc Biol. 2005; 25:1665-1670. [PubMed: 15933245]

98. Houard X, Ollivier V, Louedec L, Michel JB, Back M. Differential inflammatory activity across human abdominal aortic aneurysms reveals neutrophil-derived leukotriene B4 as a major chemotactic factor released from the intraluminal thrombus. Faseb J. 2009; 23:1376-1383. [PubMed: 19136615]

99. Tardif JC, L'Allier PL, Ibrahim R, Gregoire JC, Nozza A, Cossette M, Kouz S, Lavoie MA, Paquin J, Brotz TM, Taub R, Pressacco J. Treatment with 5-lipoxygenase inhibitor VIA-2291 (Atreleuton) in patients with recent acute coronary syndrome. Circ Cardiovasc Imaging. 3:298307. [PubMed: 20190281]

100. Hakonarson H, Thorvaldsson S, Helgadottir A, Gudbjartsson D, Zink F, Andresdottir M, Manolescu A, Arnar DO, Andersen K, Sigurdsson A, Thorgeirsson G, Jonsson A, Agnarsson U, Bjornsdottir H, Gottskalksson G, Einarsson A, Gudmundsdottir H, Adalsteinsdottir AE, Gudmundsson K, Kristjansson K, Hardarson T, Kristinsson A, Topol EJ, Gulcher J, Kong A, Gurney M, Thorgeirsson G, Stefansson K. Effects of a 5-lipoxygenase-activating protein inhibitor on biomarkers associated with risk of myocardial infarction: a randomized trial. Jama. 2005; 293:2245-2256. [PubMed: 15886380]

101. Alderton WK, Cooper CE, Knowles RG. Nitric oxide synthases: structure, function and inhibition. Biochem J. 2001; 357:593-615. [PubMed: 11463332]

102. Griffith OW, Stuehr DJ. Nitric oxide synthases: properties and catalytic mechanism. Annu Rev Physiol. 1995; 57:707-736. [PubMed: 7539994]

103. Janssens SP, Simouchi A, Quertermous T, Bloch DB, Bloch KD. Cloning and expression of a cDNA encoding human endothelium-derived relaxing factor/nitric oxide synthase. J Biol Chem. 1992; 267:22964-22967.

104. Vasquez-Vivar J, Kalyanaraman B, Martasek P, Hogg N, Masters BS, Karoui H, Tordo P, Pritchard KA Jr. Superoxide generation by endothelial nitric oxide synthase: the influence of cofactors. Proc Natl Acad Sci U S A. 1998; 95:9220-9225. [PubMed: 9689061]

105. Freedman JE, Li L, Sauter R, Keaney JJ. alpha-Tocopherol and protein kinase C inhibition enhance platelet-derived nitric oxide release. Faseb J. 2000; 14:2377-2379. [PubMed: 11024007]

106. Laursen JB, Somers M, Kurz S, McCann L, Warnholtz A, Freeman BA, Tarpey M, Fukai T, Harrison DG. Endothelial regulation of vasomotion in apoE-deficient mice: implications for interactions between peroxynitrite and tetrahydrobiopterin. Circulation. 2001; 103:1282-1288. [PubMed: 11238274]

107. Guzik TJ, Mussa S, Gastaldi D, Sadowski J, Ratnatunga C, Pillai R, Channon KM. Mechanisms of increased vascular superoxide production in human diabetes mellitus: role of $\mathrm{NAD}(\mathrm{P}) \mathrm{H}$ 
oxidase and endothelial nitric oxide synthase. Circulation. 2002; 105:1656-1662. [PubMed: 11940543]

108. Antoniades C, Shirodaria C, Leeson P, Antonopoulos A, Warrick N, Van-Assche T, Cunnington C, Tousoulis D, Pillai R, Ratnatunga C, Stefanadis C, Channon KM. Association of plasma asymmetrical dimethylarginine (ADMA) with elevated vascular superoxide production and endothelial nitric oxide synthase uncoupling: implications for endothelial function in human atherosclerosis. Eur Heart J. 2009; 30:1142-1150. [PubMed: 19297385]

109. Verhaar MC, Wever RM, Kastelein JJ, van Dam T, Koomans HA, Rabelink TJ. 5methyltetrahydrofolate, the active form of folic acid, restores endothelial function in familial hypercholesterolemia. Circulation. 1998; 97:237-241. [PubMed: 9462523]

110. Armitage JM, Bowman L, Clarke RJ, Wallendszus K, Bulbulia R, Rahimi K, Haynes R, Parish S, Sleight P, Peto R, Collins R. Effects of homocysteine-lowering with folic acid plus vitamin B12 vs placebo on mortality and major morbidity in myocardial infarction survivors: a randomized trial. Jama. 303:2486-2494. [PubMed: 20571015]

111. Antoniades C, Shirodaria C, Warrick N, Cai S, de Bono J, Lee J, Leeson P, Neubauer S, Ratnatunga C, Pillai R, Refsum H, Channon KM. 5-methyltetrahydrofolate rapidly improves endothelial function and decreases superoxide production in human vessels: effects on vascular tetrahydrobiopterin availability and endothelial nitric oxide synthase coupling. Circulation. 2006; 114:1193-1201. [PubMed: 16940192]

112. Antoniades C, Shirodaria C, Leeson P, Baarholm OA, Van-Assche T, Cunnington C, Pillai R, Ratnatunga C, Tousoulis D, Stefanadis C, Refsum H, Channon KM. MTHFR 677 C $>$ T Polymorphism reveals functional importance for 5-methyltetrahydrofolate, not homocysteine, in regulation of vascular redox state and endothelial function in human atherosclerosis. Circulation. 2009; 119:2507-2515. [PubMed: 19398669]

113. Kuhlencordt PJ, Gyurko R, Han F, Scherrer-Crosbie M, Aretz TH, Hajjar R, Picard MH, Huang PL. Accelerated atherosclerosis, aortic aneurysm formation, and ischemic heart disease in apolipoprotein E/endothelial nitric oxide synthase double-knockout mice. Circulation. 2001; 104:448-454. [PubMed: 11468208]

114. Ozaki M, Kawashima S, Yamashita T, Hirase T, Namiki M, Inoue N, Hirata K, Yasui H, Sakurai H, Yoshida Y, Masada M, Yokoyama M. Overexpression of endothelial nitric oxide synthase accelerates atherosclerotic lesion formation in apoE-deficient mice. J Clin Invest. 2002; 110:331340. [PubMed: 12163452]

115. Bendall JK, Alp NJ, Warrick N, Cai S, Adlam D, Rockett K, Yokoyama M, Kawashima S, Channon KM. Stoichiometric relationships between endothelial tetrahydrobiopterin, endothelial NO synthase (eNOS) activity, and eNOS coupling in vivo: insights from transgenic mice with endothelial-targeted GTP cyclohydrolase 1 and eNOS overexpression. Circ Res. 2005; 97:864871. [PubMed: 16179591]

116. Alp NJ, McAteer MA, Khoo J, Choudhury RP, Channon KM. Increased endothelial tetrahydrobiopterin synthesis by targeted transgenic GTP-cyclohydrolase I overexpression reduces endothelial dysfunction and atherosclerosis in ApoE-knockout mice. Arterioscler Thromb Vasc Biol. 2004; 24:445-450. [PubMed: 14707037]

117. Takaya T, Hirata K, Yamashita T, Shinohara M, Sasaki N, Inoue N, Yada T, Goto M, Fukatsu A, Hayashi T, Alp NJ, Channon KM, Yokoyama M, Kawashima S. A specific role for eNOSderived reactive oxygen species in atherosclerosis progression. Arterioscler Thromb Vasc Biol. 2007; 27:1632-1637. [PubMed: 17463333]

118. Scherrer-Crosbie M, Ullrich R, Bloch KD, Nakajima H, Nasseri B, Aretz HT, Lindsey ML, Vancon AC, Huang PL, Lee RT, Zapol WM, Picard MH. Endothelial nitric oxide synthase limits left ventricular remodeling after myocardial infarction in mice. Circulation. 2001; 104:12861291. [PubMed: 11551881]

119. Ichinose F, Bloch KD, Wu JC, Hataishi R, Aretz HT, Picard MH, Scherrer-Crosbie M. Pressure overload-induced LV hypertrophy and dysfunction in mice are exacerbated by congenital NOS3 deficiency. Am J Physiol Heart Circ Physiol. 2004; 286:H1070-1075. [PubMed: 14644766]

120. Jones SP, Greer JJ, van Haperen R, Duncker DJ, de Crom R, Lefer DJ. Endothelial nitric oxide synthase overexpression attenuates congestive heart failure in mice. Proc Natl Acad Sci U S A. 2003; 100:4891-4896. [PubMed: 12676984] 
121. Jones SP, Greer JJ, Kakkar AK, Ware PD, Turnage RH, Hicks M, van Haperen R, de Crom R, Kawashima S, Yokoyama M, Lefer DJ. Endothelial nitric oxide synthase overexpression attenuates myocardial reperfusion injury. Am J Physiol Heart Circ Physiol. 2004; 286:H276-282. [PubMed: 12969888]

122. Janssens S, Pokreisz P, Schoonjans L, Pellens M, Vermeersch P, Tjwa M, Jans P, ScherrerCrosbie M, Picard MH, Szelid Z, Gillijns H, Van de Werf F, Collen D, Bloch KD.

Cardiomyocyte-specific overexpression of nitric oxide synthase 3 improves left ventricular performance and reduces compensatory hypertrophy after myocardial infarction. Circ Res. 2004; 94:1256-1262. [PubMed: 15044322]

123. Buys ES, Raher MJ, Blake SL, Neilan TG, Graveline AR, Passeri JJ, Llano M, Perez-Sanz TM, Ichinose F, Janssens S, Zapol WM, Picard MH, Bloch KD, Scherrer-Crosbie M. Cardiomyocyterestricted restoration of nitric oxide synthase 3 attenuates left ventricular remodeling after chronic pressure overload. Am J Physiol Heart Circ Physiol. 2007; 293:H620-627. [PubMed: 17416602]

124. Moens AL, Takimoto E, Tocchetti CG, Chakir K, Bedja D, Cormaci G, Ketner EA, Majmudar M, Gabrielson K, Halushka MK, Mitchell JB, Biswal S, Channon KM, Wolin MS, Alp NJ, Paolocci N, Champion HC, Kass DA. Reversal of cardiac hypertrophy and fibrosis from pressure overload by tetrahydrobiopterin: efficacy of recoupling nitric oxide synthase as a therapeutic strategy. Circulation. 2008; 117:2626-2636. [PubMed: 18474817]

125. Miyoshi T, Li Y, Shih DM, Wang X, Laubach VE, Matsumoto AH, Helm GA, Lusis AJ, Shi W. Deficiency of inducible NO synthase reduces advanced but not early atherosclerosis in apolipoprotein E-deficient mice. Life Sci. 2006; 79:525-531. [PubMed: 16516241]

126. Detmers PA, Hernandez M, Mudgett J, Hassing H, Burton C, Mundt S, Chun S, Fletcher D, Card DJ, Lisnock J, Weikel R, Bergstrom JD, Shevell DE, Hermanowski-Vosatka A, Sparrow CP, Chao YS, Rader DJ, Wright SD, Pure E. Deficiency in inducible nitric oxide synthase results in reduced atherosclerosis in apolipoprotein E-deficient mice. J Immunol. 2000; 165:3430-3435. [PubMed: 10975863]

127. Kuhlencordt PJ, Chen J, Han F, Astern J, Huang PL. Genetic deficiency of inducible nitric oxide synthase reduces atherosclerosis and lowers plasma lipid peroxides in apolipoprotein E-knockout mice. Circulation. 2001; 103:3099-3104. [PubMed: 11425775]

128. Feng Q, Lu X, Jones DL, Shen J, Arnold JM. Increased inducible nitric oxide synthase expression contributes to myocardial dysfunction and higher mortality after myocardial infarction in mice. Circulation. 2001; 104:700-704. [PubMed: 11489778]

129. Zhang P, Xu X, Hu X, van Deel ED, Zhu G, Chen Y. Inducible nitric oxide synthase deficiency protects the heart from systolic overload-induced ventricular hypertrophy and congestive heart failure. Circ Res. 2007; 100:1089-1098. [PubMed: 17363700]

130. Mungrue IN, Gros R, You X, Pirani A, Azad A, Csont T, Schulz R, Butany J, Stewart DJ, Husain M. Cardiomyocyte overexpression of iNOS in mice results in peroxynitrite generation, heart block, and sudden death. J Clin Invest. 2002; 109:735-743. [PubMed: 11901182]

131. Gunnett CA, Lund DD, McDowell AK, Faraci FM, Heistad DD. Mechanisms of inducible nitric oxide synthase-mediated vascular dysfunction. Arterioscler Thromb Vasc Biol. 2005; 25:16171622. [PubMed: 15933248]

132. Kuhlencordt PJ, Hotten S, Schodel J, Rutzel S, Hu K, Widder J, Marx A, Huang PL, Ertl G. Atheroprotective effects of neuronal nitric oxide synthase in apolipoprotein e knockout mice. Arterioscler Thromb Vasc Biol. 2006; 26:1539-1544. [PubMed: 16627802]

133. Khan SA, Lee K, Minhas KM, Gonzalez DR, Raju SV, Tejani AD, Li D, Berkowitz DE, Hare JM. Neuronal nitric oxide synthase negatively regulates xanthine oxidoreductase inhibition of cardiac excitation-contraction coupling. Proc Natl Acad Sci U S A. 2004; 101:15944-15948. [PubMed: 15486091]

134. Dawson D, Lygate CA, Zhang MH, Hulbert K, Neubauer S, Casadei B. nNOS gene deletion exacerbates pathological left ventricular remodeling and functional deterioration after myocardial infarction. Circulation. 2005; 112:3729-3737. [PubMed: 16344403]

135. Saraiva RM, Minhas KM, Raju SV, Barouch LA, Pitz E, Schuleri KH, Vandegaer K, Li D, Hare JM. Deficiency of neuronal nitric oxide synthase increases mortality and cardiac remodeling after 
myocardial infarction: role of nitroso-redox equilibrium. Circulation. 2005; 112:3415-3422. [PubMed: 16301341]

136. Loyer X, Gomez AM, Milliez P, Fernandez-Velasco M, Vangheluwe P, Vinet L, Charue D, Vaudin E, Zhang W, Sainte-Marie Y, Robidel E, Marty I, Mayer B, Jaisser F, Mercadier JJ, Richard S, Shah AM, Benitah JP, Samuel JL, Heymes C. Cardiomyocyte overexpression of neuronal nitric oxide synthase delays transition toward heart failure in response to pressure overload by preserving calcium cycling. Circulation. 2008; 117:3187-3198. [PubMed: 18541744]

137. Barouch LA, Cappola TP, Harrison RW, Crone JK, Rodriguez ER, Burnett AL, Hare JM. Combined loss of neuronal and endothelial nitric oxide synthase causes premature mortality and age-related hypertrophic cardiac remodeling in mice. J Mol Cell Cardiol. 2003; 35:637-644. [PubMed: 12788381]

138. Nauseef WM. Myeloperoxidase biosynthesis by a human promyelocytic leukemia cell line: insight into myeloperoxidase deficiency. Blood. 1986; 67:865-872. [PubMed: 3006833]

139. Nauseef WM, Malech HL. Analysis of the peptide subunits of human neutrophil myeloperoxidase. Blood. 1986; 67:1504-1507. [PubMed: 3008892]

140. Hazen SL, Heinecke JW. 3-Chlorotyrosine, a specific marker of myeloperoxidase-catalyzed oxidation, is markedly elevated in low density lipoprotein isolated from human atherosclerotic intima. J Clin Invest. 1997; 99:2075-2081. [PubMed: 9151778]

141. Harrison JE, Schultz J. Studies on the chlorinating activity of myeloperoxidase. J Biol Chem. 1976; 251:1371-1374. [PubMed: 176150]

142. Weiss SJ, Test ST, Eckmann CM, Roos D, Regiani S. Brominating oxidants generated by human eosinophils. Science. 1986; 234:200-203. [PubMed: 3018933]

143. Daugherty A, Dunn JL, Rateri DL, Heinecke JW. Myeloperoxidase, a catalyst for lipoprotein oxidation, is expressed in human atherosclerotic lesions. J Clin Invest. 1994; 94:437-444. [PubMed: 8040285]

144. Hazell LJ, Arnold L, Flowers D, Waeg G, Malle E, Stocker R. Presence of hypochlorite-modified proteins in human atherosclerotic lesions. J Clin Invest. 1996; 97:1535-1544. [PubMed: 8617887]

145. Fu X, Kassim SY, Parks WC, Heinecke JW. Hypochlorous acid oxygenates the cysteine switch domain of pro-matrilysin (MMP-7). A mechanism for matrix metalloproteinase activation and atherosclerotic plaque rupture by myeloperoxidase. J Biol Chem. 2001; 276:41279-41287. [PubMed: 11533038]

146. Libby P, Ridker PM, Maseri A. Inflammation and atherosclerosis. Circulation. 2002; 105:11351143. [PubMed: 11877368]

147. Abu-Soud HM, Hazen SL. Nitric oxide is a physiological substrate for mammalian peroxidases. J Biol Chem. 2000; 275:37524-37532. [PubMed: 11090610]

148. Eiserich JP, Baldus S, Brennan ML, Ma W, Zhang C, Tousson A, Castro L, Lusis AJ, Nauseef WM, White CR, Freeman BA. Myeloperoxidase, a leukocyte-derived vascular NO oxidase. Science. 2002; 296:2391-2394. [PubMed: 12089442]

149. Stocker R, Huang A, Jeranian E, Hou JY, Wu TT, Thomas SR, Keaney JF Jr. Hypochlorous acid impairs endothelium-derived nitric oxide bioactivity through a superoxide-dependent mechanism. Arterioscler Thromb Vasc Biol. 2004; 24:2028-2033. [PubMed: 15331437]

150. Xu J, Xie Z, Reece R, Pimental D, Zou MH. Uncoupling of endothelial nitric oxidase synthase by hypochlorous acid: role of $\mathrm{NAD}(\mathrm{P}) \mathrm{H}$ oxidase-derived superoxide and peroxynitrite. Arterioscler Thromb Vasc Biol. 2006; 26:2688-2695. [PubMed: 17023679]

151. Brennan ML, Anderson MM, Shih DM, Qu XD, Wang X, Mehta AC, Lim LL, Shi W, Hazen SL, Jacob JS, Crowley JR, Heinecke JW, Lusis AJ. Increased atherosclerosis in myeloperoxidasedeficient mice. J Clin Invest. 2001; 107:419-430. [PubMed: 11181641]

152. McMillen TS, Heinecke JW, LeBoeuf RC. Expression of human myeloperoxidase by macrophages promotes atherosclerosis in mice. Circulation. 2005; 111:2798-2804. [PubMed: 15911707] 
153. Wang Z, Nicholls SJ, Rodriguez ER, Kummu O, Horkko S, Barnard J, Reynolds WF, Topol EJ, DiDonato JA, Hazen SL. Protein carbamylation links inflammation, smoking, uremia and atherogenesis. Nat Med. 2007; 13:1176-1184. [PubMed: 17828273]

154. Kutter D, Devaquet P, Vanderstocken G, Paulus JM, Marchal V, Gothot A. Consequences of total and subtotal myeloperoxidase deficiency: risk or benefit ? Acta Haematol. 2000; 104:10-15. [PubMed: 11111115]

155. Zhang R, Brennan ML, Fu X, Aviles RJ, Pearce GL, Penn MS, Topol EJ, Sprecher DL, Hazen SL. Association between myeloperoxidase levels and risk of coronary artery disease. Jama. 2001; 286:2136-2142. [PubMed: 11694155]

156. Ndrepepa G, Braun S, Mehilli J, von Beckerath N, Schomig A, Kastrati A. Myeloperoxidase level in patients with stable coronary artery disease and acute coronary syndromes. Eur J Clin Invest. 2008; 38:90-96. [PubMed: 18226042]

157. Duzguncinar O, Yavuz B, Hazirolan T, Deniz A, Tokgozoglu SL, Akata D, Demirpence E. Plasma myeloperoxidase is related to the severity of coronary artery disease. Acta Cardiol. 2008; 63:147-152. [PubMed: 18468192]

158. Meuwese MC, Stroes ES, Hazen SL, van Miert JN, Kuivenhoven JA, Schaub RG, Wareham NJ, Luben R, Kastelein JJ, Khaw KT, Boekholdt SM. Serum myeloperoxidase levels are associated with the future risk of coronary artery disease in apparently healthy individuals: the EPICNorfolk Prospective Population Study. J Am Coll Cardiol. 2007; 50:159-165. [PubMed: 17616301]

159. Zheng L, Nukuna B, Brennan ML, Sun M, Goormastic M, Settle M, Schmitt D, Fu X, Thomson L, Fox PL, Ischiropoulos H, Smith JD, Kinter M, Hazen SL. Apolipoprotein A-I is a selective target for myeloperoxidase-catalyzed oxidation and functional impairment in subjects with cardiovascular disease. J Clin Invest. 2004; 114:529-541. [PubMed: 15314690]

160. Bergt C, Pennathur S, Fu X, Byun J, O’Brien K, McDonald TO, Singh P, Anantharamaiah GM, Chait A, Brunzell J, Geary RL, Oram JF, Heinecke JW. The myeloperoxidase product hypochlorous acid oxidizes HDL in the human artery wall and impairs ABCA1-dependent cholesterol transport. Proc Natl Acad Sci U S A. 2004; 101:13032-13037. [PubMed: 15326314]

161. Marsche G, Furtmuller PG, Obinger C, Sattler W, Malle E. Hypochlorite-modified high-density lipoprotein acts as a sink for myeloperoxidase in vitro. Cardiovasc Res. 2008; 79:187-194. [PubMed: 18296711]

162. Shao B, Oda MN, Oram JF, Heinecke JW. Myeloperoxidase: an oxidative pathway for generating dysfunctional high-density lipoprotein. Chem Res Toxicol. 23:447-454. [PubMed: 20043647]

163. Kenmoku S, Urano Y, Kojima H, Nagano T. Development of a highly specific rhodamine-based fluorescence probe for hypochlorous acid and its application to real-time imaging of phagocytosis. J Am Chem Soc. 2007; 129:7313-7318. [PubMed: 17506554]

164. Utsumi H, Muto E, Masuda S, Hamada A. In vivo ESR measurement of free radicals in whole mice. Biochem Biophys Res Commun. 1990; 172:1342-1348. [PubMed: 2173921]

165. Utsumi H, Yasukawa K, Soeda T, Yamada K, Shigemi R, Yao T, Tsuneyoshi M. Noninvasive mapping of reactive oxygen species by in vivo electron spin resonance spectroscopy in indomethacin-induced gastric ulcers in rats. J Pharmacol Exp Ther. 2006; 317:228-235. [PubMed: 16339915]

166. Zhang R, Brennan ML, Shen Z, MacPherson JC, Schmitt D, Molenda CE, Hazen SL. Myeloperoxidase functions as a major enzymatic catalyst for initiation of lipid peroxidation at sites of inflammation. J Biol Chem. 2002; 277:46116-46122. [PubMed: 12359714]

167. Sorescu D, Szocs K, Griendling KK. NAD(P)H oxidases and their relevance to atherosclerosis. Trends Cardiovasc Med. 2001; 11:124-131. [PubMed: 11686001]

168. Witztum JL, Steinberg D. The oxidative modification hypothesis of atherosclerosis: does it hold for humans? Trends Cardiovasc Med. 2001; 11:93-102. [PubMed: 11686009]

169. Mehta JL, Li DY. Identification and autoregulation of receptor for OX-LDL in cultured human coronary artery endothelial cells. Biochem Biophys Res Commun. 1998; 248:511-514. [PubMed: 9703956]

170. Yla-Herttuala S, Palinski W, Rosenfeld ME, Parthasarathy S, Carew TE, Butler S, Witztum JL, Steinberg D. Evidence for the presence of oxidatively modified low density lipoprotein in 
atherosclerotic lesions of rabbit and man. J Clin Invest. 1989; 84:1086-1095. [PubMed: 2794046]

171. Holvoet P, Mertens A, Verhamme P, Bogaerts K, Beyens G, Verhaeghe R, Collen D, Muls E, Van de Werf F. Circulating oxidized LDL is a useful marker for identifying patients with coronary artery disease. Arterioscler Thromb Vasc Biol. 2001; 21:844-848. [PubMed: 11348884]

172. Holvoet P, Vanhaecke J, Janssens S, Van de Werf F, Collen D. Oxidized LDL and malondialdehyde-modified LDL in patients with acute coronary syndromes and stable coronary artery disease. Circulation. 1998; 98:1487-1494. [PubMed: 9769301]

173. Toshima S, Hasegawa A, Kurabayashi M, Itabe H, Takano T, Sugano J, Shimamura K, Kimura J, Michishita I, Suzuki T, Nagai R. Circulating oxidized low density lipoprotein levels. A biochemical risk marker for coronary heart disease. Arterioscler Thromb Vasc Biol. 2000; 20:2243-2247. [PubMed: 11031210]

174. Ehara S, Ueda M, Naruko T, Haze K, Itoh A, Otsuka M, Komatsu R, Matsuo T, Itabe H, Takano T, Tsukamoto Y, Yoshiyama M, Takeuchi K, Yoshikawa J, Becker AE. Elevated levels of oxidized low density lipoprotein show a positive relationship with the severity of acute coronary syndromes. Circulation. 2001; 103:1955-1960. [PubMed: 11306523]

175. Tsimikas S, Brilakis ES, Miller ER, McConnell JP, Lennon RJ, Kornman KS, Witztum JL, Berger PB. Oxidized phospholipids, Lp(a) lipoprotein, and coronary artery disease. N Engl J Med. 2005; 353:46-57. [PubMed: 16000355]

176. Inoue T, Uchida T, Kamishirado H, Takayanagi K, Hayashi T, Morooka S. Clinical significance of antibody against oxidized low density lipoprotein in patients with atherosclerotic coronary artery disease. J Am Coll Cardiol. 2001; 37:775-779. [PubMed: 11693751]

177. Miyazaki T, Shimada K, Sato O, Kotani K, Kume A, Sumiyoshi K, Sato Y, Ohmura H, Watanabe Y, Mokuno H, Daida H. Circulating malondialdehyde-modified LDL and atherogenic lipoprotein profiles measured by nuclear magnetic resonance spectroscopy in patients with coronary artery disease. Atherosclerosis. 2005; 179:139-145. [PubMed: 15721020]

178. Hulthe J, Fagerberg B. Circulating oxidized LDL is associated with subclinical atherosclerosis development and inflammatory cytokines (AIR Study). Arterioscler Thromb Vasc Biol. 2002; 22:1162-1167. [PubMed: 12117732]

179. Meisinger C, Baumert J, Khuseyinova N, Loewel H, Koenig W. Plasma oxidized low-density lipoprotein, a strong predictor for acute coronary heart disease events in apparently healthy, middle-aged men from the general population. Circulation. 2005; 112:651-657. [PubMed: 16043640]

180. Malle E, Waeg G, Schreiber R, Grone EF, Sattler W, Grone HJ. Immunohistochemical evidence for the myeloperoxidase/H2O2/halide system in human atherosclerotic lesions: colocalization of myeloperoxidase and hypochlorite-modified proteins. Eur J Biochem. 2000; 267:4495-4503. [PubMed: 10880973]

181. Sugiyama S, Okada Y, Sukhova GK, Virmani R, Heinecke JW, Libby P. Macrophage myeloperoxidase regulation by granulocyte macrophage colony-stimulating factor in human atherosclerosis and implications in acute coronary syndromes. Am J Pathol. 2001; 158:879-891. [PubMed: 11238037]

182. Vita JA, Brennan ML, Gokce N, Mann SA, Goormastic M, Shishehbor MH, Penn MS, Keaney JF Jr, Hazen SL. Serum myeloperoxidase levels independently predict endothelial dysfunction in humans. Circulation. 2004; 110:1134-1139. [PubMed: 15326065]

183. Apple FS, Pearce LA, Chung A, Ler R, Murakami MM. Multiple biomarker use for detection of adverse events in patients presenting with symptoms suggestive of acute coronary syndrome. Clin Chem. 2007; 53:874-881. [PubMed: 17384009]

184. Baldus S, Heeschen C, Meinertz T, Zeiher AM, Eiserich JP, Munzel T, Simoons ML, Hamm CW. Myeloperoxidase serum levels predict risk in patients with acute coronary syndromes. Circulation. 2003; 108:1440-1445. [PubMed: 12952835]

185. Cavusoglu E, Ruwende C, Eng C, Chopra V, Yanamadala S, Clark LT, Pinsky DJ, Marmur JD. Usefulness of baseline plasma myeloperoxidase levels as an independent predictor of myocardial infarction at two years in patients presenting with acute coronary syndrome. Am J Cardiol. 2007; 99:1364-1368. [PubMed: 17493461] 
186. Dominguez-Rodriguez A, Samimi-Fard S, Abreu-Gonzalez P, Garcia-Gonzalez MJ, Kaski JC. Prognostic value of admission myeloperoxidase levels in patients with ST-segment elevation myocardial infarction and cardiogenic shock. Am J Cardiol. 2008; 101:1537-1540. [PubMed: 18489929]

187. Khan SQ, Kelly D, Quinn P, Davies JE, Ng LL. Myeloperoxidase aids prognostication together with N-terminal pro-B-type natriuretic peptide in high-risk patients with acute ST elevation myocardial infarction. Heart. 2007; 93:826-831. [PubMed: 17194712]

188. Mocatta TJ, Pilbrow AP, Cameron VA, Senthilmohan R, Frampton CM, Richards AM, Winterbourn CC. Plasma concentrations of myeloperoxidase predict mortality after myocardial infarction. J Am Coll Cardiol. 2007; 49:1993-2000. [PubMed: 17512353]

189. Morrow DA, Sabatine MS, Brennan ML, de Lemos JA, Murphy SA, Ruff CT, Rifai N, Cannon $\mathrm{CP}$, Hazen SL. Concurrent evaluation of novel cardiac biomarkers in acute coronary syndrome: myeloperoxidase and soluble CD40 ligand and the risk of recurrent ischaemic events in TACTICS-TIMI 18. Eur Heart J. 2008; 29:1096-1102. [PubMed: 18339606]

190. Stefanescu A, Braun S, Ndrepepa G, Koppara T, Pavaci H, Mehilli J, Schomig A, Kastrati A. Prognostic value of plasma myeloperoxidase concentration in patients with stable coronary artery disease. Am Heart J. 2008; 155:356-360. [PubMed: 18215608]

191. Brennan ML, Penn MS, Van Lente F, Nambi V, Shishehbor MH, Aviles RJ, Goormastic M, Pepoy ML, McErlean ES, Topol EJ, Nissen SE, Hazen SL. Prognostic value of myeloperoxidase in patients with chest pain. N Engl J Med. 2003; 349:1595-1604. [PubMed: 14573731]

192. Nikpoor B, Turecki G, Fournier C, Theroux P, Rouleau GA. A functional myeloperoxidase polymorphic variant is associated with coronary artery disease in French-Canadians. Am Heart J. 2001; 142:336-339. [PubMed: 11479475]

193. Asselbergs FW, Reynolds WF, Cohen-Tervaert JW, Jessurun GA, Tio RA. Myeloperoxidase polymorphism related to cardiovascular events in coronary artery disease. Am J Med. 2004; 116:429-430. [PubMed: 15006595]

194. Baldus S, Rudolph V, Roiss M, Ito WD, Rudolph TK, Eiserich JP, Sydow K, Lau D, Szocs K, Klinke A, Kubala L, Berglund L, Schrepfer S, Deuse T, Haddad M, Risius T, Klemm H, Reichenspurner HC, Meinertz T, Heitzer T. Heparins increase endothelial nitric oxide bioavailability by liberating vessel-immobilized myeloperoxidase. Circulation. 2006; 113:18711878. [PubMed: 16606792]

195. Leculier C, Couprie N, Adeleine P, Leitienne P, Francina A, Richard M. The effects of high molecular weight- and low molecular weight-heparins on superoxide ion production and degranulation by human polymorphonuclear leukocytes. Thromb Res. 1993; 69:519-531. [PubMed: 8389063]

196. de Gaetano G, Cerletti C, Evangelista V. Recent advances in platelet-polymorphonuclear leukocyte interaction. Haemostasis. 1999; 29:41-49. [PubMed: 10494033]

197. Shih J, Datwyler SA, Hsu SC, Matias MS, Pacenti DP, Lueders C, Mueller C, Danne O, Mockel $\mathrm{M}$. Effect of collection tube type and preanalytical handling on myeloperoxidase concentrations. Clin Chem. 2008; 54:1076-1079. [PubMed: 18509013]

198. Morrow JD, Hill KE, Burk RF, Nammour TM, Badr KF, Roberts LJ 2nd. A series of prostaglandin F2-like compounds are produced in vivo in humans by a non-cyclooxygenase, free radical-catalyzed mechanism. Proc Natl Acad Sci U S A. 1990; 87:9383-9387. [PubMed: 2123555]

199. Lynch SM, Morrow JD, Roberts LJ 2nd, Frei B. Formation of non-cyclooxygenase-derived prostanoids (F2-isoprostanes) in plasma and low density lipoprotein exposed to oxidative stress in vitro. J Clin Invest. 1994; 93:998-1004. [PubMed: 8132786]

200. Morrow JD, Roberts LJ. The isoprostanes: unique bioactive products of lipid peroxidation. Prog Lipid Res. 1997; 36:1-21. [PubMed: 9373618]

201. Morrow JD. Quantification of isoprostanes as indices of oxidant stress and the risk of atherosclerosis in humans. Arterioscler Thromb Vasc Biol. 2005; 25:279-286. [PubMed: 15591226]

202. Pratico D, Rokach J, Lawson J, FitzGerald GA. F2-isoprostanes as indices of lipid peroxidation in inflammatory diseases. Chem Phys Lipids. 2004; 128:165-171. [PubMed: 15037161] 
203. Awad JA, Roberts LJ 2nd, Burk RF, Morrow JD. Isoprostanes--prostaglandin-like compounds formed in vivo independently of cyclooxygenase: use as clinical indicators of oxidant damage. Gastroenterol Clin North Am. 1996; 25:409-427. [PubMed: 9229581]

204. Roberts LJ 2nd, Morrow JD. The generation and actions of isoprostanes. Biochim Biophys Acta. 1997; 1345:121-135. [PubMed: 9106492]

205. Pratico D, FitzGerald GA. Generation of 8-epiprostaglandin F2alpha by human monocytes. Discriminate production by reactive oxygen species and prostaglandin endoperoxide synthase- 2 . J Biol Chem. 1996; 271:8919-8924. [PubMed: 8621535]

206. Pratico D, Iuliano L, Mauriello A, Spagnoli L, Lawson JA, Rokach J, Maclouf J, Violi F, FitzGerald GA. Localization of distinct F2-isoprostanes in human atherosclerotic lesions. J Clin Invest. 1997; 100:2028-2034. [PubMed: 9329967]

207. Mallat Z, Nakamura T, Ohan J, Leseche G, Tedgui A, Maclouf J, Murphy RC. The relationship of hydroxyeicosatetraenoic acids and F2-isoprostanes to plaque instability in human carotid atherosclerosis. J Clin Invest. 1999; 103:421-427. [PubMed: 9927504]

208. Vassalle C, Botto N, Andreassi MG, Berti S, Biagini A. Evidence for enhanced 8-isoprostane plasma levels, as index of oxidative stress in vivo, in patients with coronary artery disease. Coron Artery Dis. 2003; 14:213-218. [PubMed: 12702924]

209. Schwedhelm E, Bartling A, Lenzen H, Tsikas D, Maas R, Brummer J, Gutzki FM, Berger J, Frolich JC, Boger RH. Urinary 8-iso-prostaglandin F2alpha as a risk marker in patients with coronary heart disease: a matched case-control study. Circulation. 2004; 109:843-848. [PubMed: 14757688]

210. Cipollone F, Ciabattoni G, Patrignani P, Pasquale M, Di Gregorio D, Bucciarelli T, Davi G, Cuccurullo F, Patrono C. Oxidant stress and aspirin-insensitive thromboxane biosynthesis in severe unstable angina. Circulation. 2000; 102:1007-1013. [PubMed: 10961965]

211. LeLeiko RM, Vaccari CS, Sola S, Merchant N, Nagamia SH, Thoenes M, Khan BV. Usefulness of elevations in serum choline and free F2)-isoprostane to predict 30-day cardiovascular outcomes in patients with acute coronary syndrome. Am J Cardiol. 2009; 104:638-643. [PubMed: 19699337]

212. Reilly MP, Delanty N, Roy L, Rokach J, Callaghan PO, Crean P, Lawson JA, FitzGerald GA. Increased formation of the isoprostanes IPF2alpha-I and 8-epi-prostaglandin F2alpha in acute coronary angioplasty: evidence for oxidant stress during coronary reperfusion in humans. Circulation. 1997; 96:3314-3320. [PubMed: 9396422]

213. Mallat Z, Philip I, Lebret M, Chatel D, Maclouf J, Tedgui A. Elevated levels of 8-isoprostaglandin F2alpha in pericardial fluid of patients with heart failure: a potential role for in vivo oxidant stress in ventricular dilatation and progression to heart failure. Circulation. 1998; 97:1536-1539. [PubMed: 9593557]

214. Polidori MC, Pratico D, Savino K, Rokach J, Stahl W, Mecocci P. Increased F2 isoprostane plasma levels in patients with congestive heart failure are correlated with antioxidant status and disease severity. J Card Fail. 2004; 10:334-338. [PubMed: 15309701]

215. Keaney JF Jr. Circulating biomarkers in acute coronary syndromes: something different or more of the same? Circulation. 2005; 112:778-780. [PubMed: 16087806]

216. Vita JA, Keaney JF Jr, Raby KE, Morrow JD, Freedman JE, Lynch S, Koulouris SN, Hankin BR, Frei B. Low plasma ascorbic acid independently predicts the presence of an unstable coronary syndrome. J Am Coll Cardiol. 1998; 31:980-986. [PubMed: 9561997]

217. Stocker R, Yamamoto Y, McDonagh AF, Glazer AN, Ames BN. Bilirubin is an antioxidant of possible physiological importance. Science. 1987; 235:1043-1046. [PubMed: 3029864]

218. Schwertner HA, Fischer JR Jr. Comparison of various lipid, lipoprotein, and bilirubin combinations as risk factors for predicting coronary artery disease. Atherosclerosis. 2000; 150:381-387. [PubMed: 10856530]

219. Mayer M. Association of serum bilirubin concentration with risk of coronary artery disease. Clin Chem. 2000; 46:1723-1727. [PubMed: 11067805]

220. Madhavan M, Wattigney WA, Srinivasan SR, Berenson GS. Serum bilirubin distribution and its relation to cardiovascular risk in children and young adults. Atherosclerosis. 1997; 131:107-113. [PubMed: 9180251] 
221. Shimomura H, Ogawa H, Takazoe K, Soejima H, Miyamoto S, Sakamoto T, Kawano H, Suefuji H, Nishikawa H, Arai H, Hokamaki J, Kajiwara I, Kugiyama K, Yoshimura M. Comparison of urinary biopyrrin levels in acute myocardial infarction (after reperfusion therapy) versus stable angina pectoris and their usefulness in predicting subsequent cardiac events. Am J Cardiol. 2002; 90:108-111. [PubMed: 12106837]

222. Hokamaki J, Kawano H, Yoshimura M, Soejima H, Miyamoto S, Kajiwara I, Kojima S, Sakamoto T, Sugiyama S, Hirai N, Shimomura H, Nagayoshi Y, Tsujita K, Shioji I, Sasaki S, Ogawa H. Urinary biopyrrins levels are elevated in relation to severity of heart failure. J Am Coll Cardiol. 2004; 43:1880-1885. [PubMed: 15145115]

223. Blankenberg S, Rupprecht HJ, Bickel C, Torzewski M, Hafner G, Tiret L, Smieja M, Cambien F, Meyer J, Lackner KJ. Glutathione peroxidase 1 activity and cardiovascular events in patients with coronary artery disease. N Engl J Med. 2003; 349:1605-1613. [PubMed: 14573732]

224. Nagayoshi Y, Kawano H, Hokamaki J, Miyamoto S, Kojima S, Shimomura H, Tsujita K, Sakamoto T, Yoshimura M, Ogawa H. Urinary 8-hydroxy-2'-deoxyguanosine levels increase after reperfusion in acute myocardial infarction and may predict subsequent cardiac events. Am J Cardiol. 2005; 95:514-517. [PubMed: 15695143]

225. Kono Y, Nakamura K, Kimura H, Nishii N, Watanabe A, Banba K, Miura A, Nagase S, Sakuragi S, Kusano KF, Matsubara H, Ohe T. Elevated levels of oxidative DNA damage in serum and myocardium of patients with heart failure. Circ J. 2006; 70:1001-1005. [PubMed: 16864932]

226. Hackam DG, Anand SS. Emerging risk factors for atherosclerotic vascular disease: a critical review of the evidence. Jama. 2003; 290:932-940. [PubMed: 12928471]

227. Simoons ML, Serruys PW, van den Brand M, Res J, Verheugt FW, Krauss XH, Remme WJ, Bar F, de Zwaan C, van der Laarse A, et al. Early thrombolysis in acute myocardial infarction: limitation of infarct size and improved survival. J Am Coll Cardiol. 1986; 7:717-728. [PubMed: 2937825]

228. Sheehan FH, Doerr R, Schmidt WG, Bolson EL, Uebis R, von Essen R, Effert S, Dodge HT. Early recovery of left ventricular function after thrombolytic therapy for acute myocardial infarction: an important determinant of survival. J Am Coll Cardiol. 1988; 12:289-300. [PubMed: 3392324]

229. White HD, Norris RM, Brown MA, Takayama M, Maslowski A, Bass NM, Ormiston JA, Whitlock T. Effect of intravenous streptokinase on left ventricular function and early survival after acute myocardial infarction. N Engl J Med. 1987; 317:850-855. [PubMed: 2888018]

230. Bolli R, Jeroudi MO, Patel BS, DuBose CM, Lai EK, Roberts R, McCay PB. Direct evidence that oxygen-derived free radicals contribute to postischemic myocardial dysfunction in the intact dog. Proc Natl Acad Sci U S A. 1989; 86:4695-4699. [PubMed: 2543984]

231. Verma S, Anderson TJ. Fundamentals of endothelial function for the clinical cardiologist. Circulation. 2002; 105:546-549. [PubMed: 11827916]

232. Toyokuni S. Reactive oxygen species-induced molecular damage and its application in pathology. Pathol Int. 1999; 49:91-102. [PubMed: 10355961]

233. Chevion M, Jiang YD, Harel R, Berenshtein E, Uretzky G, Kitrossky N. COPPER AND IRON ARE MOBILIZED FOLLOWING MYOCARDIAL-ISCHEMIA - POSSIBLE PREDICTIVE CRITERIA FOR TISSUE-INJURY. Proceedings of the National Academy of Sciences of the United States of America. 1993; 90:1102-1106. [PubMed: 8430081]

234. Minotti G, Aust SD. Redox cycling of iron and lipid peroxidation. Lipids. 1992; 27:219-226. [PubMed: 1326072]

235. Minotti G, Aust SD. The role of iron in the initiation of lipid peroxidation. Chem Phys Lipids. 1987; 44:191-208. [PubMed: 2822270]

236. Kappus, H. Lipid peroxidation: mechanisms, analysis, enzymology and biological relevance. In: Sies, H., editor. Oxidative Stress. London: Academic Press; 1985. p. 273-310.

237. Hedlund BE, Hallaway PE. High-dose systemic iron chelation attenuates reperfusion injury. Biochem Soc Trans. 1993; 21:340-343. [PubMed: 8359492]

238. Kim JS, Jin YG, Lemasters JJ. Reactive oxygen species, but not Ca2+ overloading, trigger pHand mitochondrial permeability transition-dependent death of adult rat myocytes after ischemia-

Free Radic Biol Med. Author manuscript; available in PMC 2012 September 1. 
reperfusion. American Journal of Physiology-Heart and Circulatory Physiology. 2006; 290:H2024-H2034. [PubMed: 16399872]

239. Ferreira R, Burgos M, Milei J, Llesuy S, Molteni L, Hourquebie H, Boveris A. Effect of supplementing cardioplegic solution with deferoxamine on reperfused human myocardium. $\mathbf{J}$ Thorac Cardiovasc Surg. 1990; 100:708-714. [PubMed: 2232833]

240. Paraskevaidis IA, Iliodromitis EK, Vlahakos D, Tsiapras DP, Nikolaidis A, Marathias A, Michalis A, Kremastinos DT. Deferoxamine infusion during coronary artery bypass grafting ameliorates lipid peroxidation and protects the myocardium against reperfusion injury: immediate and long-term significance. Eur Heart J. 2005; 26:263-270. [PubMed: 15618054]

241. Effect of a novel free radical scavenger edaravone (MCI-186) on acute brain infarction. Randomized, placebo-controlled, double-blind study at multicenters. Cerebrovasc Dis. 2003; 15:222-229. [PubMed: 12715790]

242. Tsujita K, Shimomura H, Kawano H, Hokamaki J, Fukuda M, Yamashita T, Hida S, Nakamura Y, Nagayoshi Y, Sakamoto T, Yoshimura M, Arai H, Ogawa H. Effects of edaravone on reperfusion injury in patients with acute myocardial infarction. Am J Cardiol. 2004; 94:481-484. [PubMed: 15325934]

243. Tsujita K, Shimomura H, Kaikita K, Kawano H, Hokamaki J, Nagayoshi Y, Yamashita T, Fukuda M, Nakamura Y, Sakamoto T, Yoshimura M, Ogawa H. Long-term efficacy of edaravone in patients with acute myocardial infarction. Circ J. 2006; 70:832-837. [PubMed: 16799234]

244. Zamboni WA, Roth AC, Russell RC, Smoot EC. The effect of hyperbaric oxygen on reperfusion of ischemic axial skin flaps: a laser Doppler analysis. Ann Plast Surg. 1992; 28:339-341. [PubMed: 1596067]

245. Thom SR, Elbuken ME. Oxygen-dependent antagonism of lipid peroxidation. Free Radic Biol Med. 1991; 10:413-426. [PubMed: 1654290]

246. O’Neill WW, Martin JL, Dixon SR, Bartorelli AL, Trabattoni D, Oemrawsingh PV, Atsma DE, Chang M, Marquardt W, Oh JK, Krucoff MW, Gibbons RJ, Spears JR. Acute Myocardial Infarction with Hyperoxemic Therapy (AMIHOT): a prospective, randomized trial of intracoronary hyperoxemic reperfusion after percutaneous coronary intervention. J Am Coll Cardiol. 2007; 50:397-405. [PubMed: 17662390]

247. Stone GW, Martin JL, de Boer MJ, Margheri M, Bramucci E, Blankenship JC, Metzger DC, Gibbons RJ, Lindsay BS, Weiner BH, Lansky AJ, Krucoff MW, Fahy M, Boscardin WJ. Effect of supersaturated oxygen delivery on infarct size after percutaneous coronary intervention in acute myocardial infarction. Circ Cardiovasc Interv. 2009; 2:366-375. [PubMed: 20031745]

248. Bolli R, Becker L, Gross G, Mentzer R Jr, Balshaw D, Lathrop DA. Myocardial protection at a crossroads: the need for translation into clinical therapy. Circ Res. 2004; 95:125-134. [PubMed: 15271864]

249. Cannon RO 3rd. Mechanisms, management and future directions for reperfusion injury after acute myocardial infarction. Nat Clin Pract Cardiovasc Med. 2005; 2:88-94. [PubMed: 16265379]

250. Sawyer DB, Siwik DA, Xiao L, Pimentel DR, Singh K, Colucci WS. Role of oxidative stress in myocardial hypertrophy and failure. J Mol Cell Cardiol. 2002; 34:379-388. [PubMed: 11991728]

251. Korantzopoulos P, Galaris D, Papaioannides D, Siogas K. The possible role of oxidative stress in heart failure and the potential of antioxidant intervention. Med Sci Monit. 2003; 9:RA120-125. [PubMed: 12824962]

252. Zweier JL, Rayburn BK, Flaherty JT, Weisfeldt ML. Recombinant superoxide dismutase reduces oxygen free radical concentrations in reperfused myocardium. J Clin Invest. 1987; 80:17281734. [PubMed: 3680525]

253. Rajagopalan S, Politi PM, Sinha BK, Myers CE. Adriamycin-induced free radical formation in the perfused rat heart: implications for cardiotoxicity. Cancer Res. 1988; 48:4766-4769. [PubMed: 2842038]

254. Vaage J, Antonelli M, Bufi M, Irtun O, DeBlasi RA, Corbucci GG, Gasparetto A, Semb AG. Exogenous reactive oxygen species deplete the isolated rat heart of antioxidants. Free Radic Biol Med. 1997; 22:85-92. [PubMed: 8958132]

255. Dhalla AK, Singal PK. Antioxidant changes in hypertrophied and failing guinea pig hearts. Am J Physiol. 1994; 266:H1280-1285. [PubMed: 8184905] 
256. Hill MF, Singal PK. Right and left myocardial antioxidant responses during heart failure subsequent to myocardial infarction. Circulation. 1997; 96:2414-2420. [PubMed: 9337218]

257. Lebovitz RM, Zhang H, Vogel H, Cartwright J Jr, Dionne L, Lu N, Huang S, Matzuk MM. Neurodegeneration, myocardial injury, and perinatal death in mitochondrial superoxide dismutase-deficient mice. Proc Natl Acad Sci U S A. 1996; 93:9782-9787. [PubMed: 8790408]

258. Khaper N, Singal PK. Effects of afterload-reducing drugs on pathogenesis of antioxidant changes and congestive heart failure in rats. J Am Coll Cardiol. 1997; 29:856-861. [PubMed: 9091534]

259. Dhalla AK, Hill MF, Singal PK. Role of oxidative stress in transition of hypertrophy to heart failure. J Am Coll Cardiol. 1996; 28:506-514. [PubMed: 8800132]

260. Shiomi T, Tsutsui H, Matsusaka H, Murakami K, Hayashidani S, Ikeuchi M, Wen J, Kubota T, Utsumi H, Takeshita A. Overexpression of glutathione peroxidase prevents left ventricular remodeling and failure after myocardial infarction in mice. Circulation. 2004; 109:544-549. [PubMed: 14744974]

261. Wang G, Hamid T, Keith RJ, Zhou G, Partridge CR, Xiang X, Kingery JR, Lewis RK, Li Q, Rokosh DG, Ford R, Spinale FG, Riggs DW, Srivastava S, Bhatnagar A, Bolli R, Prabhu SD. Cardioprotective and antiapoptotic effects of heme oxygenase- 1 in the failing heart. Circulation. 121:1912-1925. [PubMed: 20404253]

262. Li T, Singal PK. Adriamycin-induced early changes in myocardial antioxidant enzymes and their modulation by probucol. Circulation. 2000; 102:2105-2110. [PubMed: 11044428]

263. Bolli R, Jeroudi MO, Patel BS, Aruoma OI, Halliwell B, Lai EK, McCay PB. Marked reduction of free radical generation and contractile dysfunction by antioxidant therapy begun at the time of reperfusion. Evidence that myocardial "stunning" is a manifestation of reperfusion injury. Circ Res. 1989; 65:607-622. [PubMed: 2548761]

264. Gross GJ, O’Rourke ST, Pelc LR, Warltier DC. Myocardial and endothelial dysfunction after multiple, brief coronary occlusions: role of oxygen radicals. Am J Physiol. 1992; 263:H17031709. [PubMed: 1481896]

265. Qin F, Shite J, Liang CS. Antioxidants attenuate myocyte apoptosis and improve cardiac function in CHF: association with changes in MAPK pathways. Am J Physiol Heart Circ Physiol. 2003; 285:H822-832. [PubMed: 12714335]

266. Nakamura R, Egashira K, Machida Y, Hayashidani S, Takeya M, Utsumi H, Tsutsui H, Takeshita A. Probucol attenuates left ventricular dysfunction and remodeling in tachycardia-induced heart failure: roles of oxidative stress and inflammation. Circulation. 2002; 106:362-367. [PubMed: 12119254]

267. Sia YT, Parker TG, Liu P, Tsoporis JN, Adam A, Rouleau JL. Improved post-myocardial infarction survival with probucol in rats: effects on left ventricular function, morphology, cardiac oxidative stress and cytokine expression. J Am Coll Cardiol. 2002; 39:148-156. [PubMed: 11755301]

268. Redout EM, van der Toorn A, Zuidwijk MJ, van de Kolk CW, van Echteld CJ, Musters RJ, van Hardeveld C, Paulus WJ, Simonides WS. Antioxidant treatment attenuates pulmonary arterial hypertension-induced heart failure. Am J Physiol Heart Circ Physiol. 298:H1038-1047. [PubMed: 20061549]

269. Hamblin M, Smith HM, Hill MF. Dietary supplementation with vitamin E ameliorates cardiac failure in type I diabetic cardiomyopathy by suppressing myocardial generation of 8-isoprostaglandin F2alpha and oxidized glutathione. J Card Fail. 2007; 13:884-892. [PubMed: 18068623]

270. Minhas KM, Saraiva RM, Schuleri KH, Lehrke S, Zheng M, Saliaris AP, Berry CE, Barouch LA, Vandegaer KM, Li D, Hare JM. Xanthine oxidoreductase inhibition causes reverse remodeling in rats with dilated cardiomyopathy. Circ Res. 2006; 98:271-279. [PubMed: 16357304]

271. Heymes C, Bendall JK, Ratajczak P, Cave AC, Samuel JL, Hasenfuss G, Shah AM. Increased myocardial NADPH oxidase activity in human heart failure. J Am Coll Cardiol. 2003; 41:2164 2171. [PubMed: 12821241]

272. Sam F, Kerstetter DL, Pimental DR, Mulukutla S, Tabaee A, Bristow MR, Colucci WS, Sawyer DB. Increased reactive oxygen species production and functional alterations in antioxidant enzymes in human failing myocardium. J Card Fail. 2005; 11:473-480. [PubMed: 16105639] 
273. Anker SD, Doehner W, Rauchhaus M, Sharma R, Francis D, Knosalla C, Davos CH, Cicoira M, Shamim W, Kemp M, Segal R, Osterziel KJ, Leyva F, Hetzer R, Ponikowski P, Coats AJ. Uric acid and survival in chronic heart failure: validation and application in metabolic, functional, and hemodynamic staging. Circulation. 2003; 107:1991-1997. [PubMed: 12707250]

274. Krishnan E. Hyperuricemia and incident heart failure. Circ Heart Fail. 2009; 2:556-562. [PubMed: 19919980]

275. Ahmed MI, Gladden JD, Litovsky SH, Lloyd SG, Gupta H, Inusah S, Denney T Jr, Powell P, McGiffin DC, Dell'Italia LJ. Increased oxidative stress and cardiomyocyte myofibrillar degeneration in patients with chronic isolated mitral regurgitation and ejection fraction $>60 \%$. $\mathrm{J}$ Am Coll Cardiol. 55:671-679. [PubMed: 20170794]

276. Cappola TP, Kass DA, Nelson GS, Berger RD, Rosas GO, Kobeissi ZA, Marban E, Hare JM. Allopurinol improves myocardial efficiency in patients with idiopathic dilated cardiomyopathy. Circulation. 2001; 104:2407-2411. [PubMed: 11705816]

277. Farquharson CA, Butler R, Hill A, Belch JJ, Struthers AD. Allopurinol improves endothelial dysfunction in chronic heart failure. Circulation. 2002; 106:221-226. [PubMed: 12105162]

278. George J, Carr E, Davies J, Belch JJ, Struthers A. High-dose allopurinol improves endothelial function by profoundly reducing vascular oxidative stress and not by lowering uric acid. Circulation. 2006; 114:2508-2516. [PubMed: 17130343]

279. Hare JM, Mangal B, Brown J, Fisher C Jr, Freudenberger R, Colucci WS, Mann DL, Liu P, Givertz MM, Schwarz RP. Impact of oxypurinol in patients with symptomatic heart failure. Results of the OPT-CHF study. J Am Coll Cardiol. 2008; 51:2301-2309. [PubMed: 18549913]

280. George J, Struthers A. The OPT-CHF (Oxypurinol Therapy for Congestive Heart Failure) trial: a question of dose. J Am Coll Cardiol. 2009; 53:2405. [PubMed: 19539154]

281. Gokce N, Keaney JF Jr, Frei B, Holbrook M, Olesiak M, Zachariah BJ, Leeuwenburgh C, Heinecke JW, Vita JA. Long-term ascorbic acid administration reverses endothelial vasomotor dysfunction in patients with coronary artery disease. Circulation. 1999; 99:3234-3240. [PubMed: 10385496]

282. Kugiyama K, Motoyama T, Hirashima O, Ohgushi M, Soejima H, Misumi K, Kawano H, Miyao Y, Yoshimura M, Ogawa H, Matsumura T, Sugiyama S, Yasue H. Vitamin C attenuates abnormal vasomotor reactivity in spasm coronary arteries in patients with coronary spastic angina. J Am Coll Cardiol. 1998; 32:103-109. [PubMed: 9669256]

283. Motoyama T, Kawano H, Kugiyama K, Hirashima O, Ohgushi M, Tsunoda R, Moriyama Y, Miyao Y, Yoshimura M, Ogawa H, Yasue H. Vitamin E administration improves impairment of endothelium-dependent vasodilation in patients with coronary spastic angina. J Am Coll Cardiol. 1998; 32:1672-1679. [PubMed: 9822095]

284. Keith ME, Jeejeebhoy KN, Langer A, Kurian R, Barr A, O’Kelly B, Sole MJ. A controlled clinical trial of vitamin $\mathrm{E}$ supplementation in patients with congestive heart failure. Am J Clin Nutr. 2001; 73:219-224. [PubMed: 11157316]

285. Weant KA, Smith KM. The role of coenzyme Q10 in heart failure. Ann Pharmacother. 2005; 39:1522-1526. [PubMed: 16046484]

286. Kirk EA, Dinauer MC, Rosen H, Chait A, Heinecke JW, LeBoeuf RC. Impaired superoxide production due to a deficiency in phagocyte NADPH oxidase fails to inhibit atherosclerosis in mice. Arterioscler Thromb Vasc Biol. 2000; 20:1529-1535. [PubMed: 10845868]

287. Takimoto E, Champion HC, Li M, Ren S, Rodriguez ER, Tavazzi B, Lazzarino G, Paolocci N, Gabrielson KL, Wang Y, Kass DA. Oxidant stress from nitric oxide synthase-3 uncoupling stimulates cardiac pathologic remodeling from chronic pressure load. J Clin Invest. 2005; 115:1221-1231. [PubMed: 15841206]

288. Flogel U, Decking UK, Godecke A, Schrader J. Contribution of NO to ischemia-reperfusion injury in the saline-perfused heart: a study in endothelial NO synthase knockout mice. J Mol Cell Cardiol. 1999; 31:827-836. [PubMed: 10329210]

289. Hannan RL, John MC, Kouretas PC, Hack BD, Matherne GP, Laubach VE. Deletion of endothelial nitric oxide synthase exacerbates myocardial stunning in an isolated mouse heart model. J Surg Res. 2000; 93:127-132. [PubMed: 10945953] 
290. Jones SP, Girod WG, Palazzo AJ, Granger DN, Grisham MB, Jourd'Heuil D, Huang PL, Lefer DJ. Myocardial ischemia-reperfusion injury is exacerbated in absence of endothelial cell nitric oxide synthase. Am J Physiol. 1999; 276:H1567-1573. [PubMed: 10330240]

291. Sharp BR, Jones SP, Rimmer DM, Lefer DJ. Differential response to myocardial reperfusion injury in eNOS-deficient mice. Am J Physiol Heart Circ Physiol. 2002; 282:H2422-2426. [PubMed: 12003854]

292. Heger J, Godecke A, Flogel U, Merx MW, Molojavyi A, Kuhn-Velten WN, Schrader J. Cardiacspecific overexpression of inducible nitric oxide synthase does not result in severe cardiac dysfunction. Circ Res. 2002; 90:93-99. [PubMed: 11786524]

293. West MB, Rokosh G, Obal D, Velayutham M, Xuan YT, Hill BG, Keith RJ, Schrader J, Guo Y, Conklin DJ, Prabhu SD, Zweier JL, Bolli R, Bhatnagar A. Cardiac myocyte-specific expression of inducible nitric oxide synthase protects against ischemia/reperfusion injury by preventing mitochondrial permeability transition. Circulation. 2008; 118:1970-1978. [PubMed: 18936326]

294. Godecke A, Molojavyi A, Heger J, Flogel U, Ding Z, Jacoby C, Schrader J. Myoglobin protects the heart from inducible nitric-oxide synthase (iNOS)-mediated nitrosative stress. J Biol Chem. 2003; 278:21761-21766. [PubMed: 12665503]

295. Vasilyev N, Williams T, Brennan ML, Unzek S, Zhou X, Heinecke JW, Spitz DR, Topol EJ, Hazen SL, Penn MS. Myeloperoxidase-generated oxidants modulate left ventricular remodeling but not infarct size after myocardial infarction. Circulation. 2005; 112:2812-2820. [PubMed: 16267254]

296. Askari AT, Brennan ML, Zhou X, Drinko J, Morehead A, Thomas JD, Topol EJ, Hazen SL, Penn MS. Myeloperoxidase and plasminogen activator inhibitor 1 play a central role in ventricular remodeling after myocardial infarction. J Exp Med. 2003; 197:615-624. [PubMed: 12615902]

297. Tsutsui T, Tsutamoto T, Wada A, Maeda K, Mabuchi N, Hayashi M, Ohnishi M, Kinoshita M. Plasma oxidized low-density lipoprotein as a prognostic predictor in patients with chronic congestive heart failure. J Am Coll Cardiol. 2002; 39:957-962. [PubMed: 11897436]

298. Stephens JW, Gable DR, Hurel SJ, Miller GJ, Cooper JA, Humphries SE. Increased plasma markers of oxidative stress are associated with coronary heart disease in males with diabetes mellitus and with 10-year risk in a prospective sample of males. Clin Chem. 2006; 52:446-452. [PubMed: 16384883] 
Physiological state

Low levels of ROS

Cell growth

Stress adaptation

Promote injury response

Modify cellular phenotype

\section{Chronic antioxidants not effective or harmful}

\section{Pathological state}

\section{High levels of ROS}

Cause apoptosis/cell death

Killing pathogens(extracellular)

Attenuate cell function

Promotes tissue injury

\section{Chronic antioxidants} more likely to be effective

\section{Figure 1.}

Roles of ROS in physiological vs. pathological states. Physiological states are characterized by low levels of ROS that have been implicated in cell growth, stress adaptation, injury responses, and various modifications in cellular phenotype. In contrast, pathological states typically exhibit unregulated high levels of ROS that are linked to cellular apoptosis, killing of pathogens, impairement of cellular functions and ongoing tissue injury. 


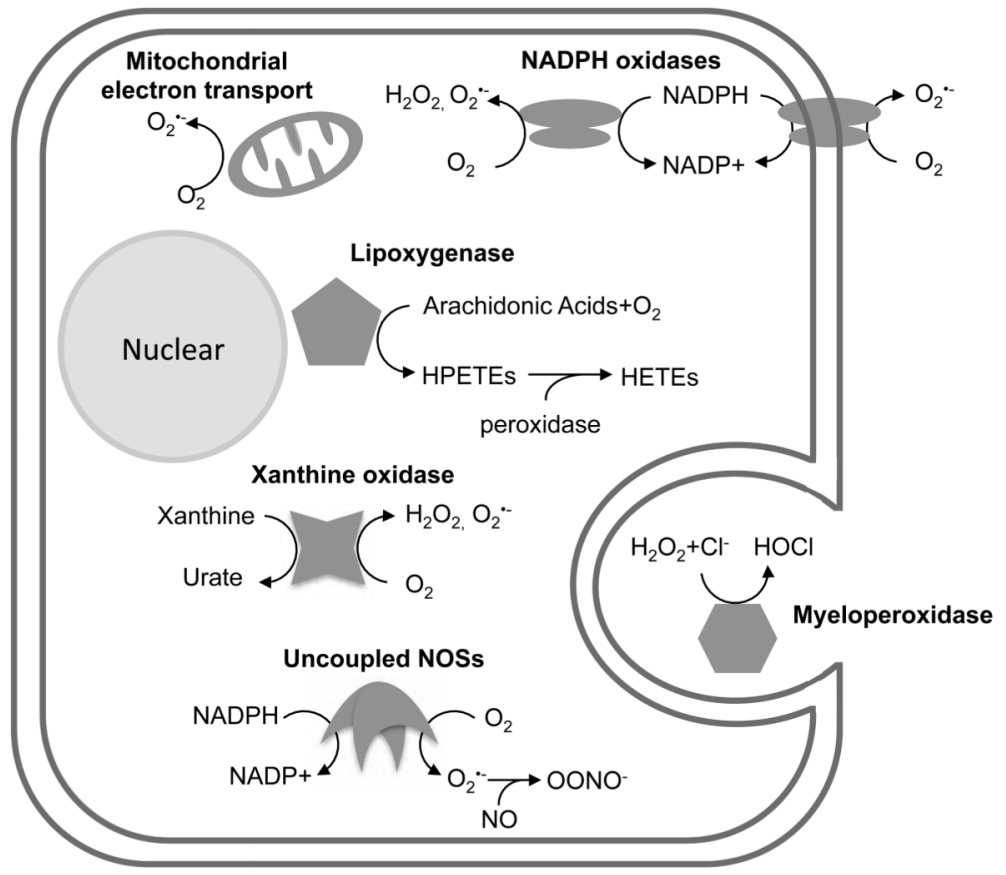

Figure 2.

Scheme depicting selected sources of ROS that are known to have implications for cardiovascular disease. Complete explanations are contained in the text. 


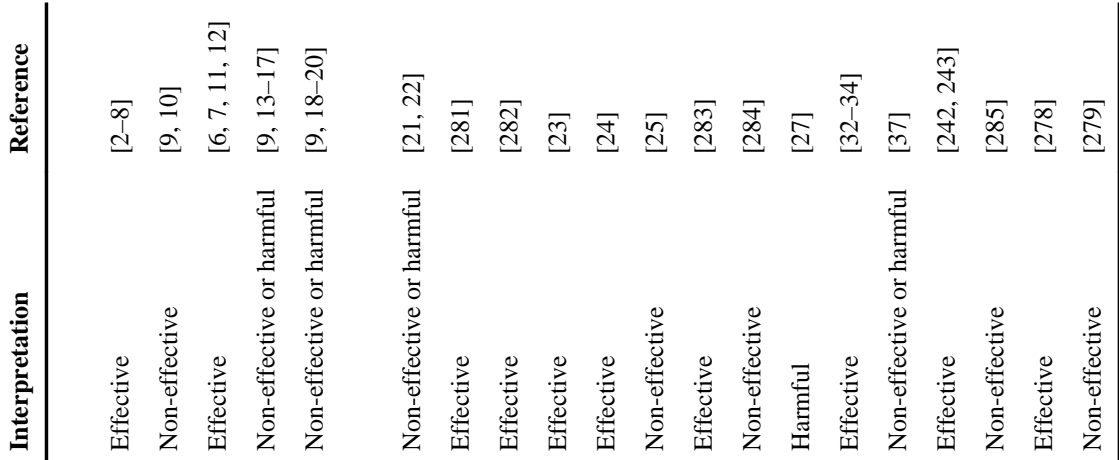
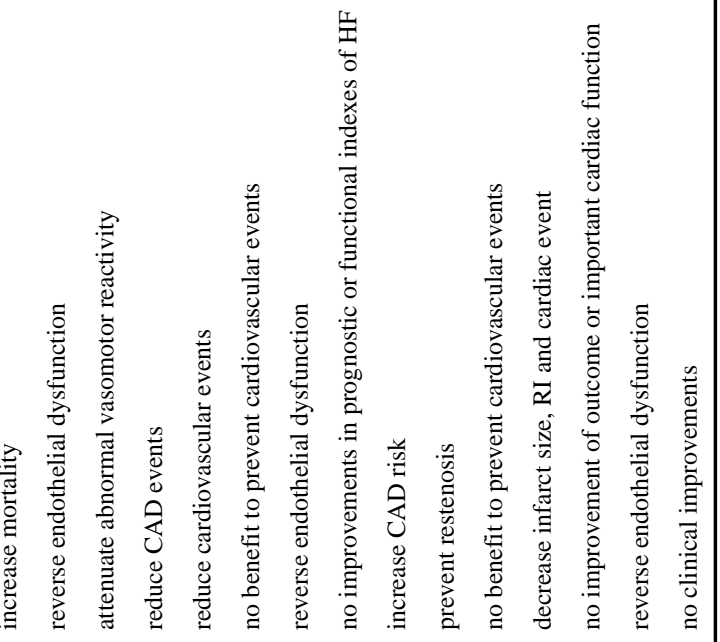

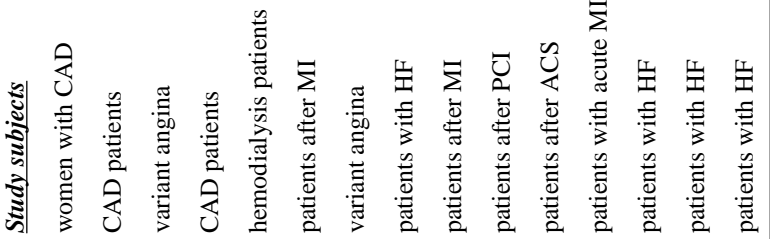




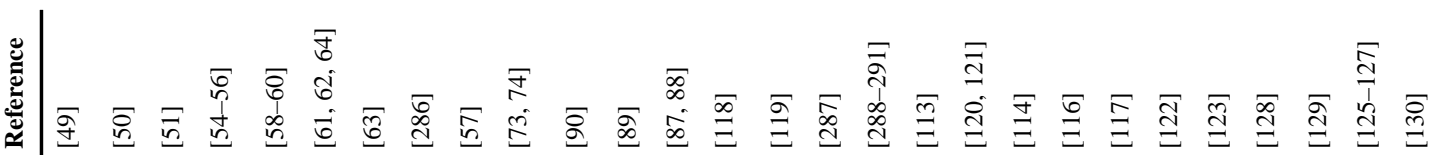

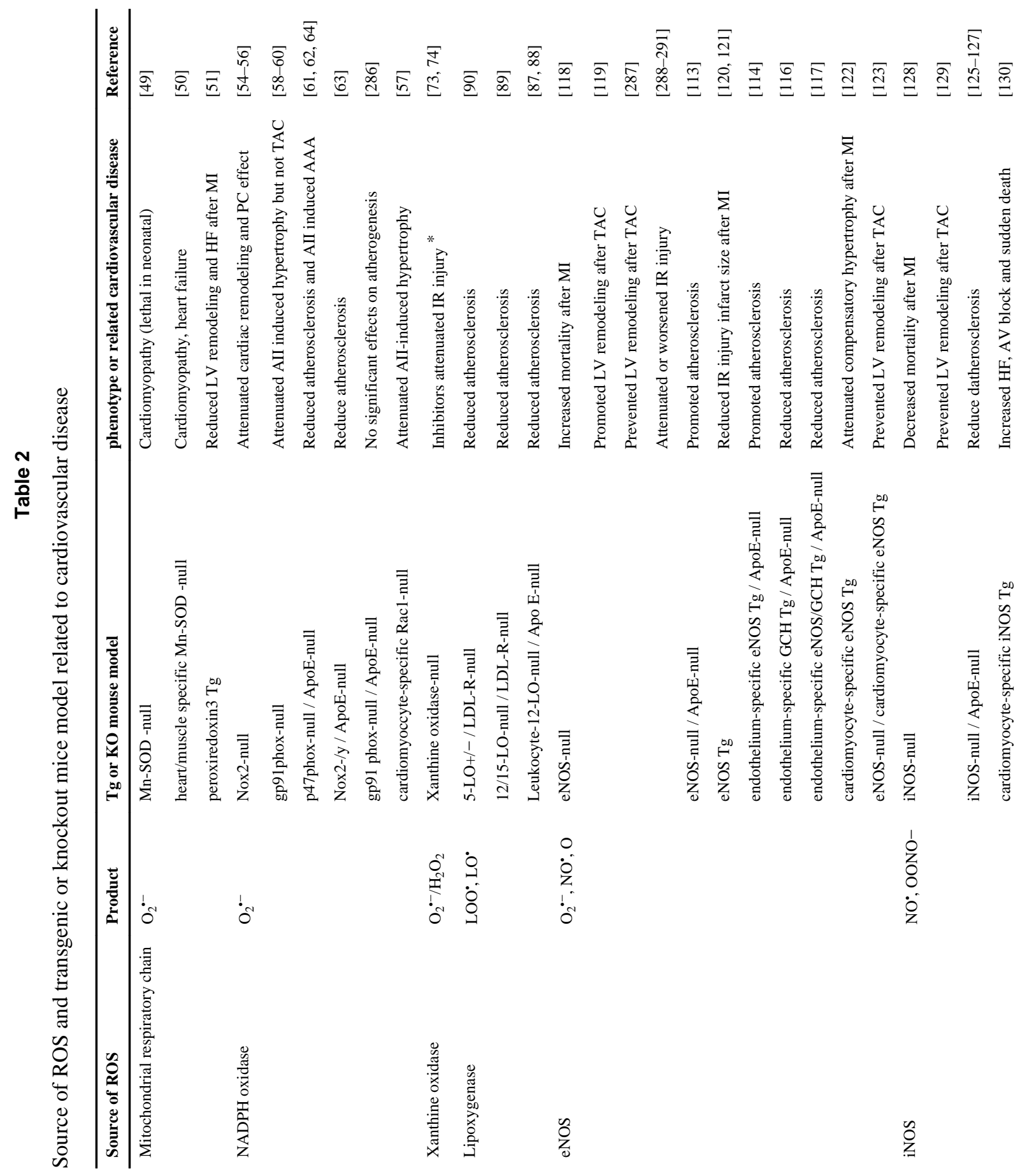




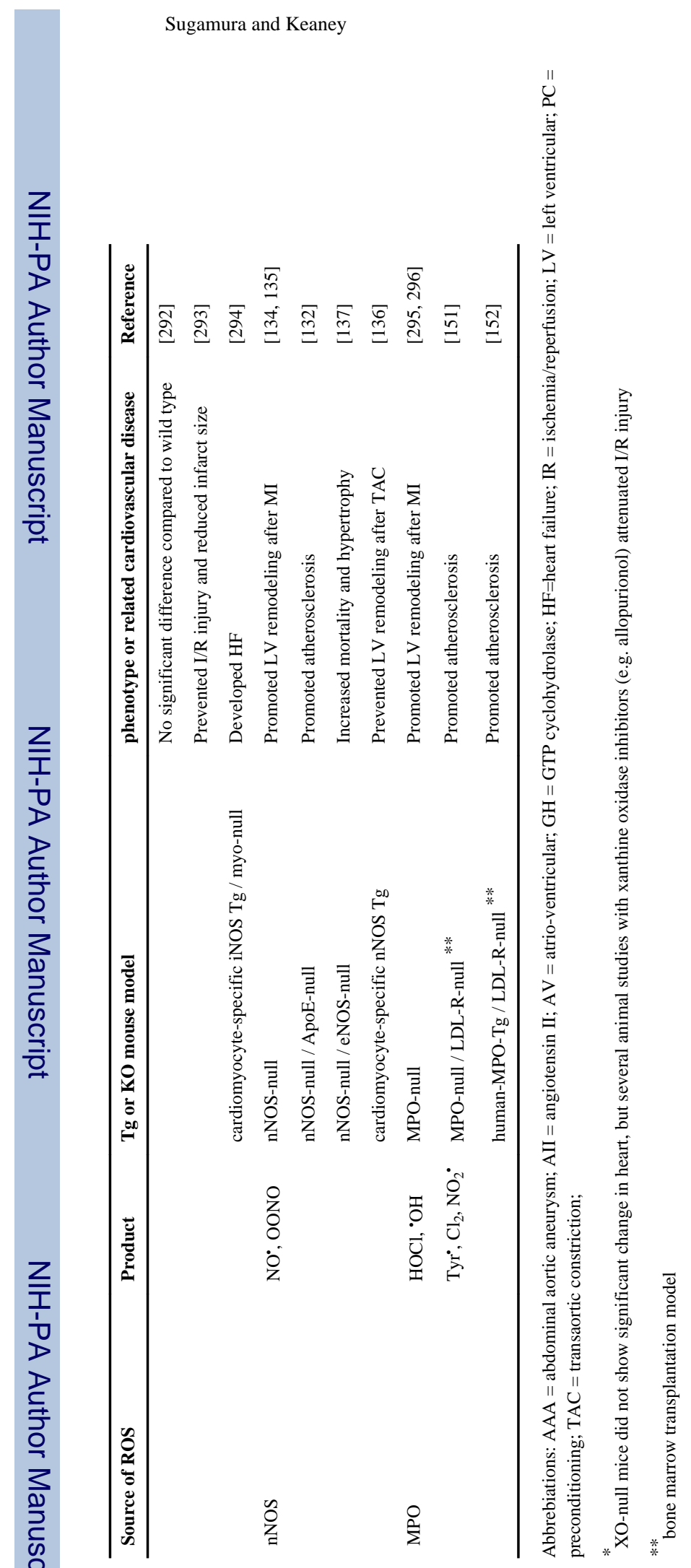

Free Radic Biol Med. Author manuscript; available in PMC 2012 September 1. 
